\section{American States of Mind}

Visions of Capitalism and Democracy among Private and Public Workers

Craig Reinarman

Working from extensive interviews held over a five-year period, Craig Reinarman examines the political beliefs of a dozen Americans and finds that political ideologies are the result of a complex interaction of one's biography and history.

"A landmark study of American political culture." -Frances Fox Piven \$25.00

\section{The $50 \%$ Solution}

How to Bargain Successfully with Hijackers, Strikers, Bosses, Oil Magnates, Arabs, Russians, and other Worthy Opponents in This Modern World

edited by I. William Zartman

Drawing on examples ranging from the Cuban missile crisis to a strike at the New York Times, the distinguished contributors to this book - now reissued with an updated bibliography - deal with such questions as: Who really wins in negotiations? How do they do it? Is the negotiation process the same in all conflicts?

"With international bargaining of increasing importance... we will have more and more reason to make use of this work in our courses." - Donald Rothchild \$40.00 cloth, \$14.95 paper

\section{Psycho/History}

Readings in the Method of Psychology, Psychoanalysis, and History

edited by Geoffrey Cocks and Travis Crosby

This anthology of eighteen definitive essays on psychohistory, written by leading psychologists, historians, sociologists, and political scientists, includes recent and contemporary arguments about the applications of psychology to history. \$35.00 cloth, \$ I4.95 paper

Yale University Press

Dept. 530

92A Yale Station

New Haven, CT 06520

\section{The Rise of American}

\section{Air Power}

The Creation of Armageddon

Michael S. Sherry

In the first in-depth history of American strategic bombing, Michael S. Sherry explores the growing appeal of air power in America before World War II; the ideas, techniques, personalities, and organizations that guided air attacks during the war; and the devastating effects of American and British "conventional" bombing.

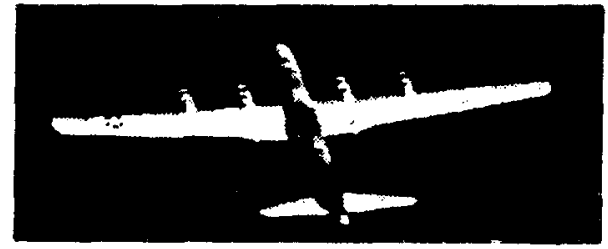

"An outstanding work."-Stephen E. Ambrose 25 illus. $\$ 29.95$

Now available in paperback

\section{A Grand Strategy for the West}

The Anachronism of National Strategies in an Interdependent World

Helmut Schmidt

Timely, original, and hard-hitting prescriptions for U.S. and Western policy from the former West German chancellor.

"A fascinating and totally engrossing book that abounds in wisdom and bite." -Cyrus Vance

"An excellent discussion of international problems, made all the better by the author's fine sense of the possible." - Alexander M. Haig, Jr. \$7.95

\section{Weapons of the Weak} Everyday Forms of Peasant Resistance

James C. Scott

"Weapons of the Weak is a brilliant book, combining a sure feel for the subjective side of struggle with a deft handling of economic and political trends." - John R. Bowen, Journal of Peasant Studies \$14.95 


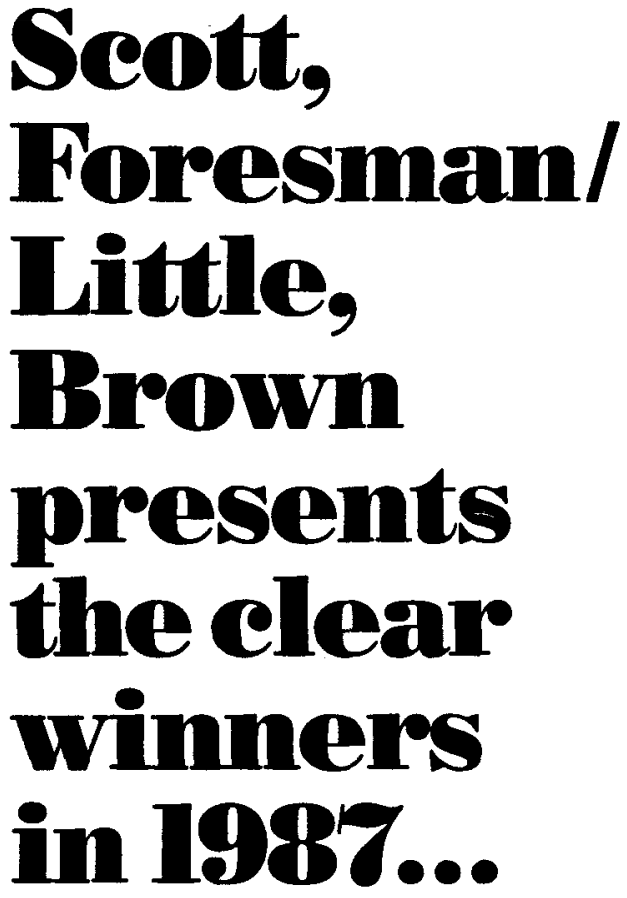

THE FOLLOWING TITLES ARE AVAILABLE NOW.

AMERICAN GOVERNMENT: Readings and Cases

Ninth Edition

Peter Woll, editor

paper/608 pages/Instructoris Manual

BEIIIND THE SCENES IN

AMERICAN GOVERNMENT: Personalities and Polities

Sixth Edition

Peter Woll, editor

paper/384 pages/Instructor's Manual

\section{AMERICAN GOVERNMENT:} Institutions, Policies, and Polities

Paul Dawson

cloth/6+8 pages/Instructors̀ Manual. Test Items.

DIPLOMA. Transparencies. and Study Guide

\section{READINGS ON AMERICAN GOVERNMENT \\ Fred R. Harris \\ paper/608 pages}

CONSTITUTIONAL

DEMOCRACY IN AMERICA:

A Reappraisal

Charles W. Dunn

paper/496 pages/Instructor's Manual, Study Guide, and Simulations

\section{THE NEW AMERICAN PRESIDENCY \\ Larry Berman \\ paper/432 pages}

\section{THE POLITICS DF CONGRESSIONAL ELECTIONS \\ Second Edition \\ Gary C. Jacobson \\ paper/272 pages}

EAGLE RESURGENT?

The Reagan Era in American Foreign Poliey

Kenneth A. Oye, Robert J. Lieber, and Donald Rothchild

paper/480 pages

\section{WAR, PEACE, AND \\ INTERNATIONAL POLITICS \\ Fourth Edition \\ David W. Ziegler \\ paper/496 pages/Instructor's Manual}

\section{FOREIGN POLICY MAKING \\ AND THE AMERICAN \\ POLITICAL SYSTEM \\ Second Edition \\ James A. Nathan and \\ James K. Oliver \\ paper/352 pages}

\section{UNDERSTANDING POLITICAL DEVELOPMENT Myron Weiner and Samuel P. Huntington, editors paper/544 pages}

managing public policy Laurence E. Lynn, Jr. paper/304 pages

\section{REGULATION:} The Polities of Poliey Michael D. Reagan paper/256 pages

\section{AN INTRODUCTION To Politics}

Alan Isaak

cloth/448 pages/Instructor's Manual 


\section{...and the leadiing candidates for $1988 .$.}

\section{IN AMERICAN GOVERNMENT...}

\section{UNDERSTANDING AMERICA'S GOVERNMENT Fred R. Harris, Randy Roberts, and Margaret Elliston}

Traditionally organized, this text blends a political science and historical perspective to show how government is always evolving. In a concise, accessible format, the text covers essential principles, institutions, processes, and policies of American government. paper/480 pages/Instructor's Manual and Study Guide

Available in December.

\section{AMERICAN}

\section{GOVERNMENT:}

\section{Poliey and Polities}

Second Edition

\section{Neal Tannahill}

Using a public policy approach, this brief introductory text carefully explains the basic institutions and processes of American government. The Second Edition offers an in-depth analysis of the U.S. Constitution, along with the latest scholarship on the Presidency, political parties, interest groups, and public opinion. paper/496 pages/Instructor's Manual and Study Guide

Available in December.

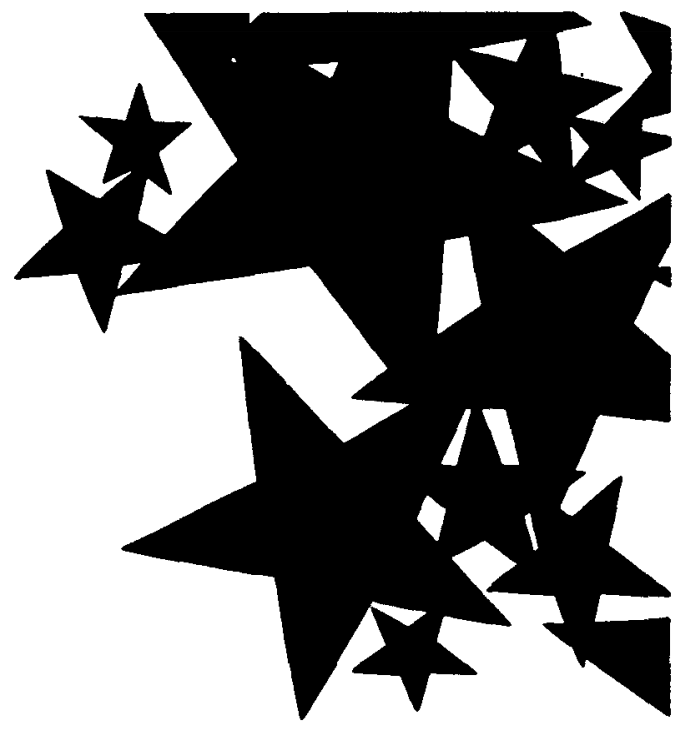

THE BASICS OF

\section{AMERICAN POLITICS Fifth Edition \\ Gary Wasserman}

Brief, basic, inexpensive, and easy to read, this core text uses an integrating theme-the comparison of politics to a complex game which revolves around the competition for power and influence - to introduce American politics. paper/304 pages/Instructor's Manual Available in November.

\section{DEBATING AMERICAN GOVERNMENT \\ Second Edition \\ Peter Woll, editor}

This lively anthology pairs off an impressive group of leading political scientists, bestselling authors, journalists, and political practitioners in a debate format that addresses contemporary issues and controversies in American government. paper/352 pages/Instructor's Manual Available in December.

\section{Scott, Foresman/ Little, Brown COLLEGE DIVISION}




\section{IN PARTIES...}

\section{THE PARTY'S JUST BEGUN: Shaping Political Parties for America's Future}

\section{Larry J. Sabato}

Professor Sabato examines the rejuvenation of the two major political parties in the late 1980 's, and considers possible strategies for regenerating partisan loyalty among the voting public and reviving the American party system. paper/288 pages

Available in December.

\section{MONEY IN AMERICAN ELECTIONS \\ Frank J. Sorauf}

This overview of campaign finance defines and analyzes the new era in the funding and regulating of electoral politics - and deals systematically with the altendant political issues that trouble many Americans. paper/256 pages

Available January 1988.

\section{PARTY POLITICS IN AMERICA \\ Sixth Edition \\ Frank J. Sorauf and Paul AIlen Beek}

This comprehensive, best selling text analyzes the historical development and the present role of parties in the American political system. The Sixth Edition examines recent changes in the status of political parties, and integrates current research and examples throughout. paper/480 pages Available in December.

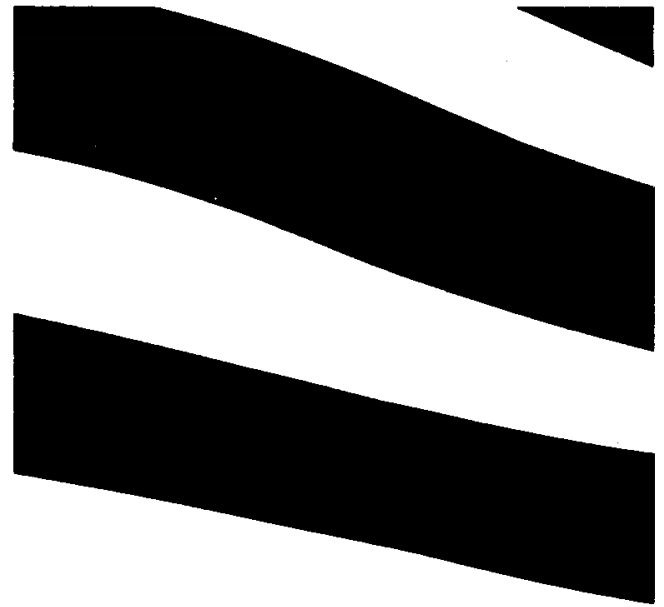

\section{AMERICAN POLITICIANS AND JOURNALISTS Charles Press and Kenneth VerBurg}

A provocative look at the relationship between politicians and journalists, this new supplementary text examines the state of guarded cooperation that exists between two groups who depend on one another to advance their own careers.

paper/256 pages

Available in November.

\section{AMERICAN PARTIES IN DECLINE \\ Third Edition \\ William Crotty}

This intriguing scholarly analysis and summary of the current state of party politics in America examines the factors that have influenced party decline and the context in which these changes have taken place.

paper/288 pages

Available January 1988.

write:

Meredith Hellestrae,

Department SAP-APSA

1900 East Lake Avenue

Glenview, Illinois 60025 


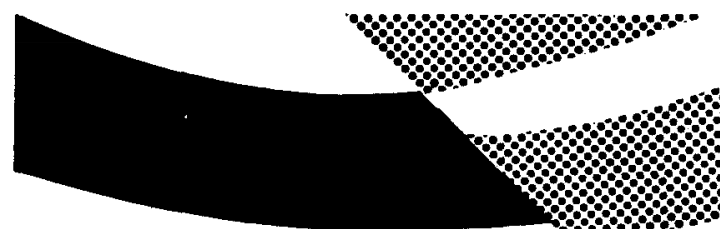

THE POLITICS DF

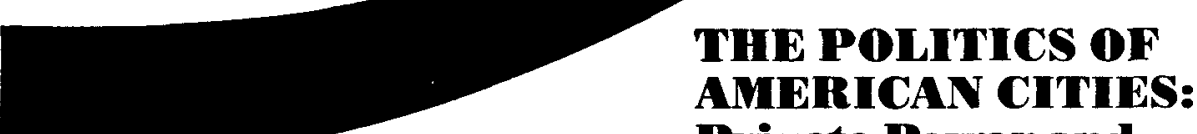

Private Power and

Public Policy

Third Edition

IN STATE/LOCAL AND URBAN/ METROPOLITAN...

\section{THE DEPENDENT CITY:}

The Changing Political

Economy of American

\section{Urban Polities Since 1789}

\section{Paul Kantor with}

\section{Stephen David}

This new text describes how the three major areas of city governmental policy - economic development, social welfare, and routine public services - have been powerfully shaped over time by changes in capitalism, federalism, and democratic institutions.

paper/288 pages

Available in February 1988.

\section{POLITICS AND}

\section{POLICY IN STATES}

\section{ANI COMMUNITIES}

\section{Third Edition}

\section{John J. Harrigan}

With an emphasis on both political process and public policy, this highly respected text analyzes the reassertiveness of American states and communities within the federal system. The Third Edition includes a new chapter on economic development policy.

cloth/512 pages/Instructor's Manual

Available in November.

\section{Dennis R. Judd}

The close relationship between public authority and the private sector is the unifying theme of this highly regarded core text. This thorough revision includes new material on the decline of party machines, the rise of the Sunbelt cities, city finances, and much more. paper/428 pages Available in December.

\section{POLITICS IN THE GOLDEN STATE: The California \\ Connection \\ Second Edition \\ Terry Christensen and \\ Larry N. Gerston}

By focusing on personalities and power struggles, this lively and timely introduction gives students truer insights into how California's political institutions actually work, into the motivations behind individuals' political actions, into the effects of those actions, and into the institutions themselves. paper/304 pages/Instructor's Manual Available in December.

\section{Scott, Foresman/ Little, Brown COLLEGE DIVISION}




\section{IN FOREIGN POLICYI INTERNATIONAL RELATIONS AND COMPARATIVE POLITICS...}

\section{COMPARATIVE POLITICS TODAY: A World View Fourth Edition \\ Gabriel A. Almond and G. Bingham Powell, Jr.} Featuring Almond's well known structural/ functional model of comparative anulysis, this new edition provides both theoretical analyses and up-to-date, detailed studies of diverse countries - all written by respected specialists in the field.

cloth/592 pages/Instructor's Manual

Available in November.

\section{NEW FORCES, OLD FORCES, AND THE FUTURE OF WORLD POLITICS}

\section{Seyom Brown}

This new text examines the dominant features of contemporary world politics, asking which are durable and most likely to play a large role in shaping the future and which are declining or only transitory in their influence. It shows that the most dangerous threats to the wellbeing of the human species are the result of a lag between world politics and economic, technological, and cultural realities - and prescribes policies and institutional reforms to overcome this lag. paper/352 pages Available in December.

\section{NO COMMON POWER: Understanding International Relations Robert J. Lieber}

This new, superbly crafted introduction to international relations offers a balance of theory and empirical analysis, historical and current topics-from a lucid, neorealist perspective. paper/448 pages/Instructor's Manual Available in November.

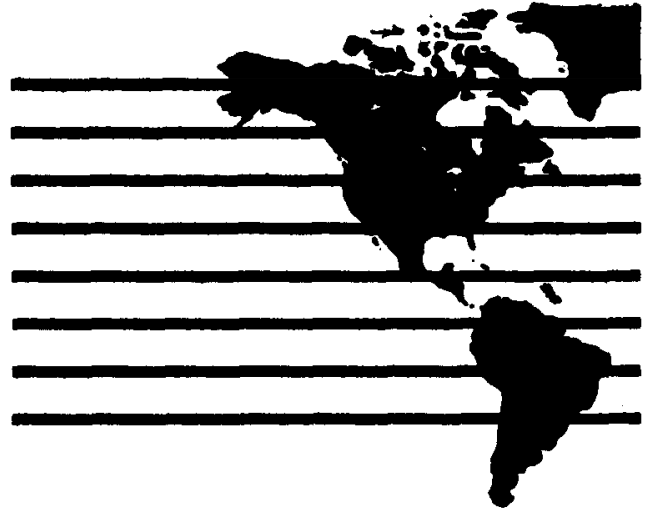

\section{PEACE IMPOSSIBLE- WAR UNLIKELY: The Cold War Between the United States and the Soviet Union Joseph L. Nogee and John W. Spanier}

From the combined expertise of two well known scholars comes this balanced analysis of postWorld War II U.S. - Soviet relations. The text covers the complex origins and long evolution of their conflict, the effects of the nuclear age and the arms race on their strategies, the nature of their rivalry in the Third World, their interactions with China, the collapse of detente, and the authors' general theory of U.S. - Soviet relations. paper/320 pages Available January 1988.

\section{THE LDGIC OF INTERNATIONAL RELATIONS Sixth Edition \\ Walter S. Jones}

This new edition of the most successful international relations text maintains its perceptual analysis approach and focuses on how national ideologies, concepts, values, and interests influence a nation's point of view. A new chapter on international political economy is included. paper/688 pages/Instructor's Manual Available in December.

write:

Meredith Hellestrae, Department SAP-APSA 1900 East Lake Avenue Glenview, Illinois 60025 


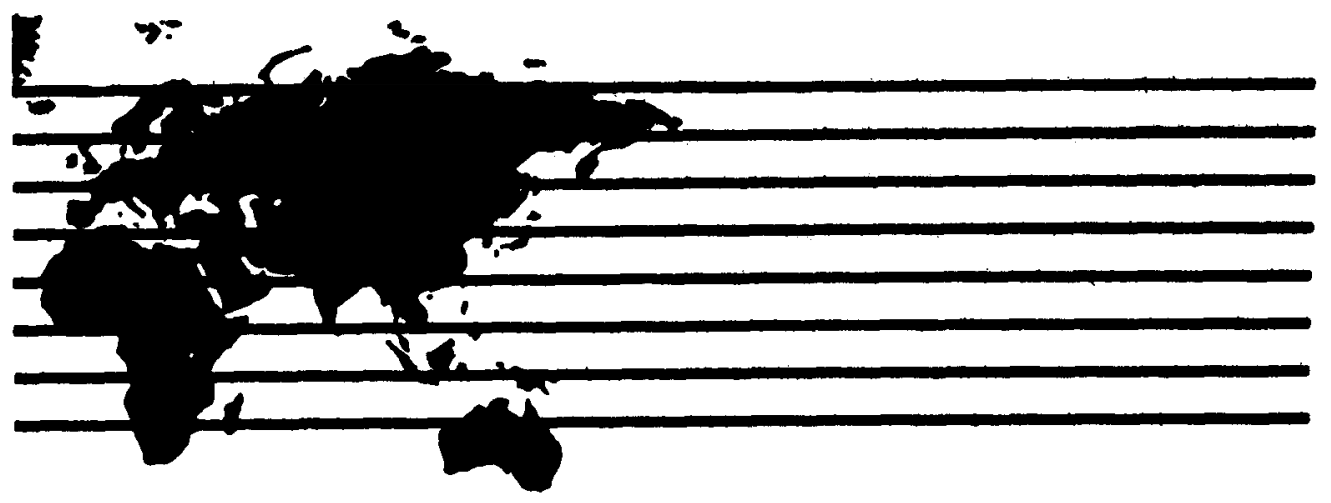

\section{IN LAW/JUDICIAL PROCESS AND PUBLIC ADMINISTRATION/ PUBLIC POLICY...}

\section{POLICY PARADOX AND POLITICAL REASON \\ Deborah Stone}

This innovative and powerful work develops a new concept of political reasoning which significantly advances our ability to explain the many paradoxes of political reality. It views society as a political community where policy is produced, and holds that policy making is a struggle over images as the constituent elements of policy goals, problems, and solutions. The struggle of political reasoning uses metaphor and analogy to categorize and differentiate, to construct and maintain boundaries, and to thus argue in strategic portrayals for policy's sake.

paper/288 pages

Available in December.

\section{THE NEW POLITICS DF THE BUDGETARY PROCESS \\ Aaron Wildavsky}

This entirely new book (except for one chapter and a few pages on the nature of budgeting) by a distinguished expert looks at the increasingly important role of the budget in national politics today. Wildavsky describes how the budget is made, examines historical influences, entitlements, and defense budgeting; and explains the reasons for the stalemates between the president and Congress on budgetary issues. paper/448 pages Available in November.

\section{REASON IN LAW}

\section{Third Edition}

\section{Lief H. Carter}

Updated throughout to reflect the latest legal developments, the Third Edition of this highly respected text continues to introduce a broad range of jurisprudential issues - in a readable and accessible style geared to undergraduates with no background in law or the legal system. paper/336 pages

Available in November.

\section{THE CONTOURS OF JUSTICE: Commumities and Their Courts James Bisonstein, Roy B. Flemming, and Peier R. Nardulii}

This new text describes the actual workings of criminal courts in nine middle-sized counties. Using the metaphor of courts as communities, the authors examine the interaction of various elements: the larger community, the technology used to schedule and assign work, local legal culture, and customary ways of disposing of cases. The twin concepts of court community and jurisdiction size provide a framework for understanding the differences among criminal courts in the U.S. paper/304 pages Now available.

\section{Scott, Foresman/ Little, Brown COLLEGE DIVISION}




\section{Paths to Peace}

Exploring the Feasibility

of Sustainable Peace

Richard Smoke with

Willis Harman

A primer on thinking about peace in the nuclear age. Describes and compares nine basic ways-ranging from deterrence to nonviolent resistance-in which people or governments have tried to achieve peace.

Aug. 1987 - ca. 106 pp. $\$ \$ 16.95$ (hc) • \$9.95 (pb)

\section{The Strategic Defense}

Initiative Shield or Snare?

\section{Harold Brown}

The former U.S. secretary of defense gathers a wide range of views on the SDI debate, including those surrounding the program's possible objectives, the availability and limits of technology, the survivability of a defense against attack, the cost-exchange ratio for the defense, and the direct and opportunity costs to the nation. In addition, Soviet perceptions of ballistic missile defense and the potential of a Soviet breakout from the ABM Treaty are considered.

Sept. 1987 • ca. 292 pp. • \$29 (sc)

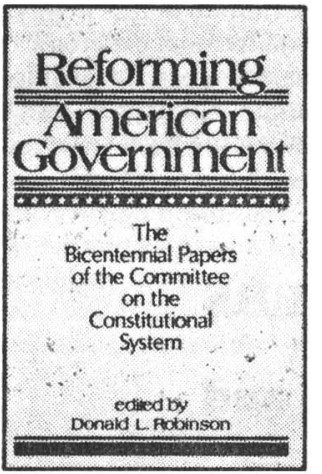

Introduction to Marx and Engels

A Critical Reconstruction

\section{Richard Schmitt}

"One of the best introductions to the thought of Marx and Engels. . . . destined to become a standard in the field. . . . surveys virtually all of the central themes in the vast Marx-Engels body of writings. ... accessible to the introductory student and a pleasure for the scholar."

-Edward S. Greenberg

University of Colorado, Boulder

Aug. 1987 ca. 212 pp. • \$32.50 (hc) • $\$ 12.95(\mathrm{pb})$

\section{Administering the New Federalism}

ed. by Lewis G. Bender and James A. Stever

"The 14 articles, of uniformly high quality, explore a broad range of issues. . . . The book's thorough review of the fiscal and administrative effects of the early Reagan years will make it a useful reference."

-Choice

TO ORDER OR TO REOUEST A CATALOG, PLEASE WRITE OR CALL:

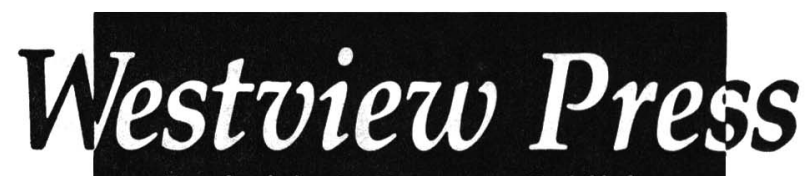

Frederick A. Praeger, Publisher 


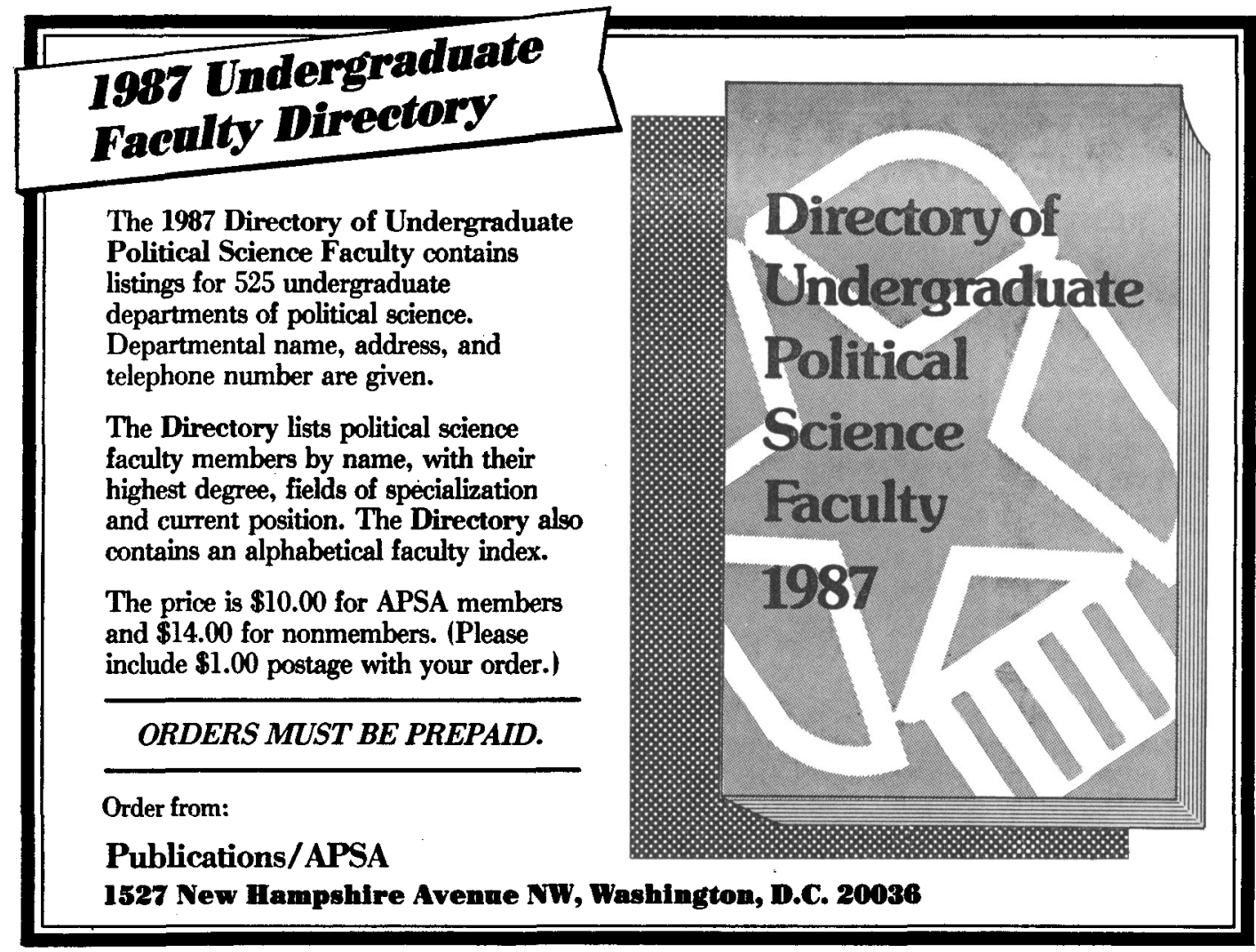

\section{The Greation of Our Constitution}

\section{THE FHDERALIST PAPERS \\ Edited and with an Introduction by Clinton Rossiter}

Written by Alexander Hamilton, James Madison, and John Jay. Based on the original McLean edition of 1788, this volume is designed especially for classroom use and examines the three Federalists' defense of the Constitution. The complete Constitution with marginal notes and an index of ideas are included.

\section{THI UTMYHD STATHS,}

An Introduction

Updated Edition

By Floyd G. Cullop. This illuminating guide to the document that is the backbone to the American nation is updated to include coverage of the 26th Amendment and other changes to the government since 1969. Helpful quizzes are spaced throughout the text.

D MENTOR 0-452-62431-8 \$2.95/\$3.50*

\section{THE LIVIYG U.S.

CONSTITUTION

Second Revleed Edition by

Jacob $W$. Landynaki

By Saul K. Padover. This study of constitutional law takes into account the judicial issues raised by Watergate, the Supreme Court ruling on abortion, and a number of landmark decisions. Also included are a complete text of the Constitution, appendices, and chronology.

- MENTOR 0-451-62174-3 \$4.95/\$4.95*

\footnotetext{
-Prices in Canada. Prices sublect to change. Write to the Education Department at the address below for a free History \& Political Science catalog.
}

\section{THE ANTI-FEDERALIST PAPERS AND THE CONSTITUTONAL CONVFHIION DEBATES}

Edited and with an Introduction by Raiph Ketcham. This complete collection of original documents gives full voice to the dissenting opinions of statesmen such as Patrick Henry and DeWitt Clinton, who felt the proposed Constitution threatened individual rights and liberties. DENTOR ORICINAL 0-451-62525-0 \$4.95/5.95*

\section{WITIISSES AT THE CREATION}

Hamilion, Madison, Jay, and the Constitution by Richard B. Morris. The author, one of the most respected Constitutional historians in the country, describes how these three founding fathers collaborated on writing The Federalists and promoted the passage of the Constitution. - PLUME 0-452-25867-7 \$9.95/13.95* 


\section{THE FOURTH EDITION OF. . .}

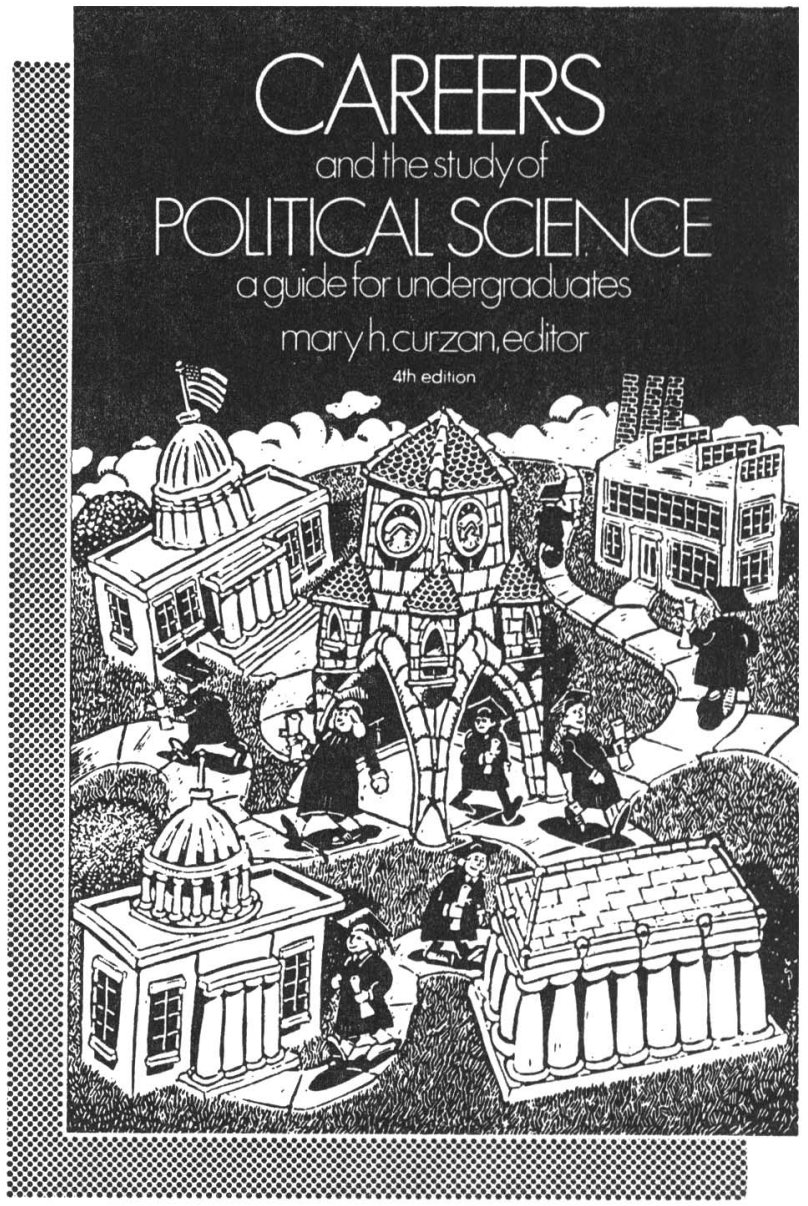

Careers discusses the relationship between the study of political science and careers in law, government, interest groups and associations, international organizations, business, journalism, and teaching.

Single copies are available for $\$ 2.00$ each; orders under 50 copies must be PREPAID.

$\begin{array}{rccc}\text { Bulk Orders } & \begin{array}{c}\text { APSA Departmental } \\ \text { Service Member }\end{array} & \begin{array}{c}\text { Non-Member } \\ \text { Ratal }\end{array} \\ 10 \text { copies } & \$ 7.50 & \$ 10.00 & \$ 1.00 \\ 50 \text { copies } & \$ 30.00 & \$ 40.00 & \$ 2.50 \\ 100 \text { copies } & \$ 50.00 & \$ 70.00 & \$ 4.00\end{array}$

Order from:

Publications/APSA

1527 New Hampshire Avenue, N.W.

Washington, D.C. 20036 


\section{Books that matter are Basic}

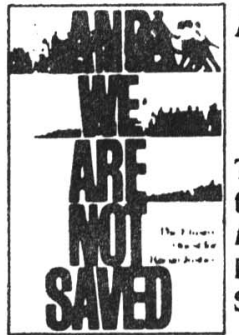

Breaking

the

impasse

Procticol Approoches to

Resolving Púlic Dispute

LAWRENCE SUSSKIND ond KEFREY CRUIKSHANK

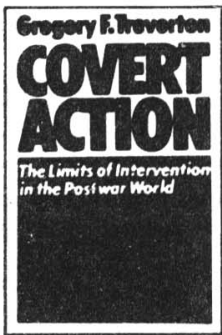

If I Had a

Hammer.

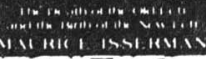

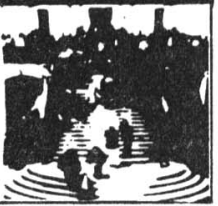

And We Are Not Saved

The Elusive Quest for

Racial Reform

DERRICK BELL

The tragedy of civil rights-an intellectual and literary tour de force by a brilliant Harvard Law Professor.

September

$\$ 19.95$

\section{Breaking the Impasse}

Practical Approaches to

Resolving Public Disputes

LAWRENCE SUSSKIND \&

JEFFREY CRUIKSHANK

Tested, concensus-building strategies for resolving public disputes by one of this country's top mediators.

$\$ 18.95$

November

\section{Covert Action}

The Limits of Intervention in the Postwar World GREGORY T. TREVERTON Our postwar experience with covert action and what we can learn from it by a leading intelligence expert.

$\$ 19.95$ October

If I Had a Hammer... The Death of the Old Left and the Birth of the New Left MAURICE ISSERMAN A probing search for the roots of rebellion in an age of political conformity. September

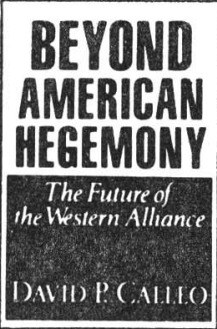

Beyond American Hegemony

The Future of

the Western Alliance DAVID P. CALLEO

A path-breaking reassessment of the Western Alliance and a compelling case for greater European involvement. $\$ 20.95$ October

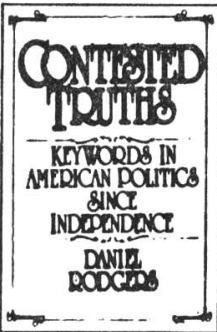

\section{Contested Truths}

Keywords in American Politics Since Independence DANIEL T. RODGERS

A compelling challenge to the myth of a concensus. \$19.95 September

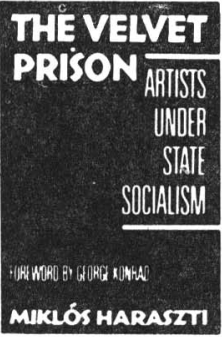

\section{The Velvet Prison}

Artists Under State Socialism MIKLOS HARASZTI

This urgent message to the West from one of Hungary's leading dissident writers is a major contribution to our understanding of the modem totalitarian mentality. October

$\$ 14.95$

\section{Social Security}

The System that Works MERTON C. BERNSTEIN \&

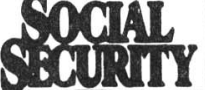
JOAN BRODSHAUG BERNSTEIN

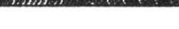

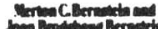

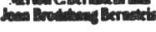
A vivid, insiders' account of social security-how it works, what was behind its recent "crisis," and why it can be counted on, unlike pri. vate pensions. $\$ 21.95$ November

\section{now in paperback}

Democracy and Capitalism

Property, Community, and the Contradictions of Modem Social Thought SAMUEL BOWLES \& HERBERT GINTIS $\$ 8.95$ September

\section{The Party Goes On}

The Persistence of the Two-Party System in the United States XANDRA KAYDEN \& EDDIE MAHE, JR. $\$ 8.95$ September

\section{A World of Secrets}

The Uses and Limits of Intelligence WALTER LAQUEUR $\$ 11.95$

$\$ 9.95$ 


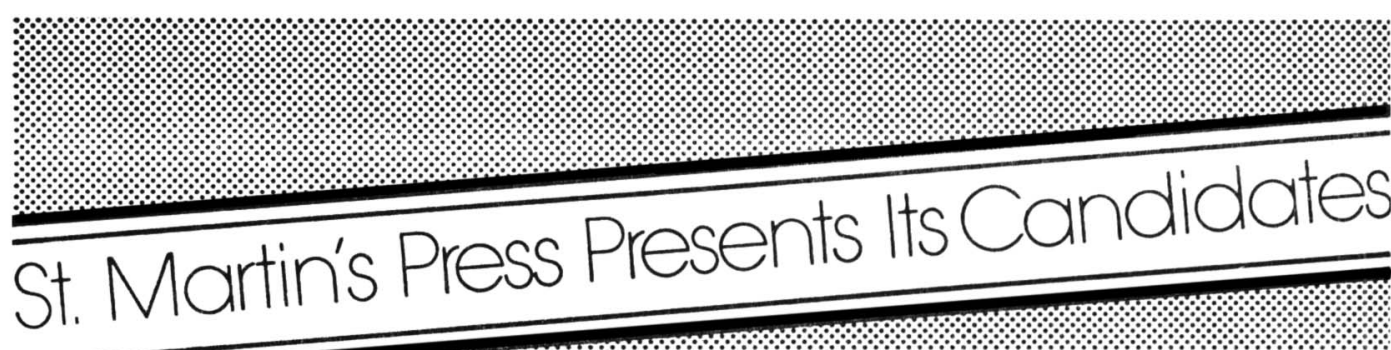

\section{American Government: READINGS ON CONTINUITY AND CHANGE \\ ROBERT HARMEL, Texas A\&M University}

This text offers a collection of 60 readings-articles, documents, and cases-all by leading authorities in the field. The readings are tied together by the theme of "continuity and change," and the book's organization parallels that of all the major American government texts.

Paperbound. 600 pages (probable).

Publication: January 1988

Instructor's Manual available
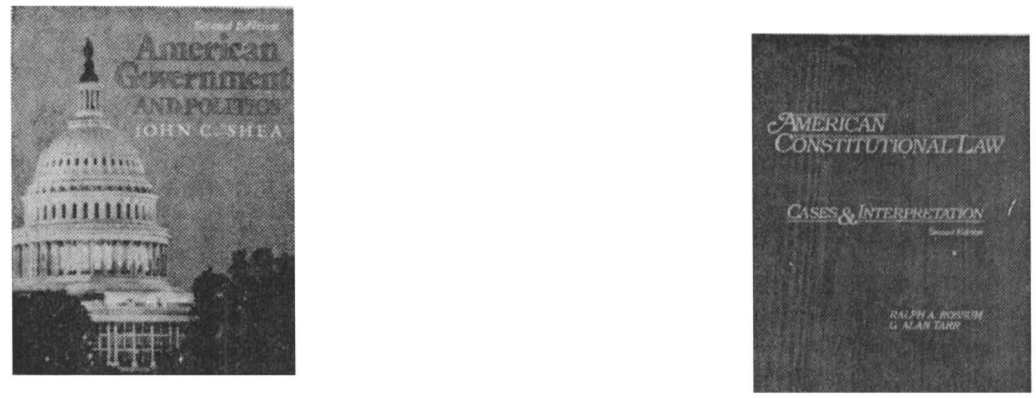

\section{American Government and Politics \\ Second Edition \\ JOHN C. SHEA, West Chester \\ University of Pennsylvania}

A basic yet comprehensive introduction, this book provides an in-depth description of the foundations, influences on, and institutions of American government. The author uses pertinent examples throughout to help students connect today's headlines to the principles and history of American government and politics. The second edition features new or expanded coverage of such topics as political culture, the media and PACs, civil rights, and public policy.

Paperbound. 544 pages. 1987

Instructor's Manual and Test Item File available

\section{American \\ Constitutional Law CASES AND INTERPRETATION \\ Second Edition}

RALPH A. ROSSUM, Claremont McKenna College G. ALAN TARR, Rutgers University, Camden

This topically organized text for the American constitutional law course focuses on constitutional interpretation in order to help students analyze the activity of the Court. Included are introductory essays, selected court cases, headnotes and endnotes for each case, and a glossary. New to the second edition are constitutionally significant Court decisions and Congressional pronouncements since 1982. 704 pages. 1987 


\section{Government Courses....}

\section{The Road to the White House THE POLITICS OF PRESIDENTIAL ELECTIONS \\ Third Edition \\ STEPHEN J.WAYNE, George Washington University}

This third edition was written with the 1988 presidential campaign in mind. Like its highly successful predecessors, it begins with the earliest preprimary candidate strategies and takes the reader all the way to election day. The third edition incorporates recent political science literature and a discussion of the new Democratic party rule changes and their likely impact on the 1988 campaign as well as revised, updated, and expanded chapters.

Paperbound. 319 pages.

Publication: November 1987

Prepublication examination copies now available

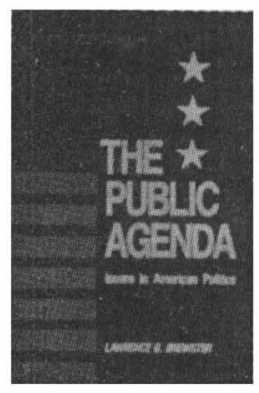

\section{The Public Agenda}

\section{ISSUES IN AMERICAN POLITICS}

Revised Second Edition

LAWRENCE G. BREWSTER,

San Jose State University

A thorough analysis of seven key current issues in American politics-the economy, energy, health care, immigration, toxic wastes, crime, and the arms race. New to this edition is the chapter on immigration as well as revised and expanded coverage of all the other issues.

Paperbound. 304 pages 1987

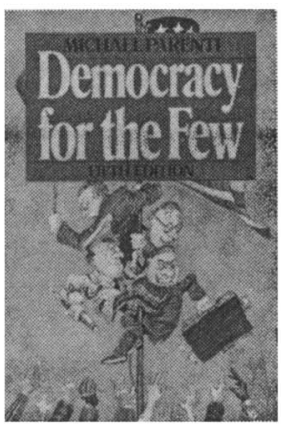

\section{Democracy for the Few Fifth Edition \\ MICHAEL PARENTI}

A provocative book for American government courses that challenges the status quo; all the standard topics of the American government course are covered-but from a radical perspective rather than the conventional pluralist stance. The reader is drawn into a critical analysis of a system that the author believes favors the powerful and the rich. Virtually every chapter in this Fifth Edition has been updated, and new material has been added on topics ranging from public bureaucracy to nuclear power. Paperbound. 350 pages (probable).

Publication: November 1987

Prepublication examination copies now available

To request an examination copy of any of these titles, please write us on your college letterhead, specifying the title of your course, present text, and approximate enrollment. Send your request to:

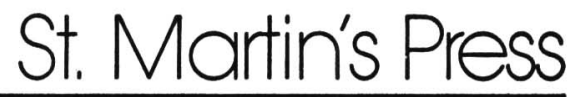




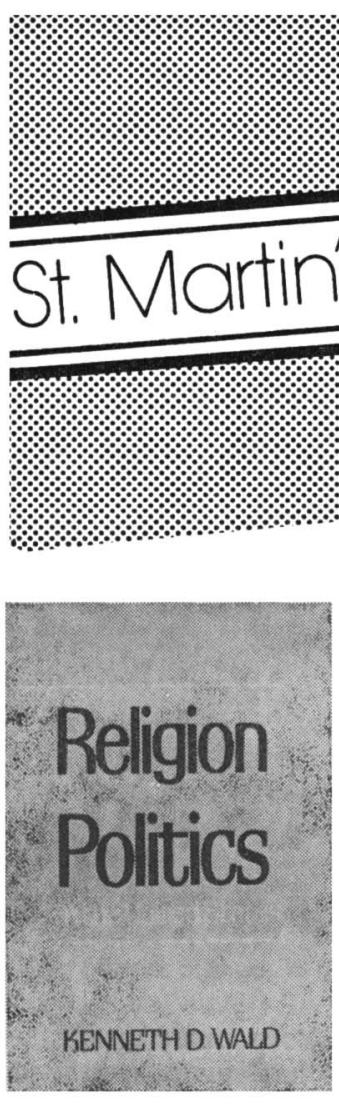

\section{Religion and Politics in the United States}

KENNETH D. WALD, University of Florida

This brief but inclusive text examines the impact of religious values, institutions, and communities on the conduct of political life in the United States. The author puts forth hard data and perennial questions in order to further understanding of traditional conflicts in church-state relations and recent debates over such issues as abortion and nuclear disarmament.

Paperbound. 301 pages. 1987

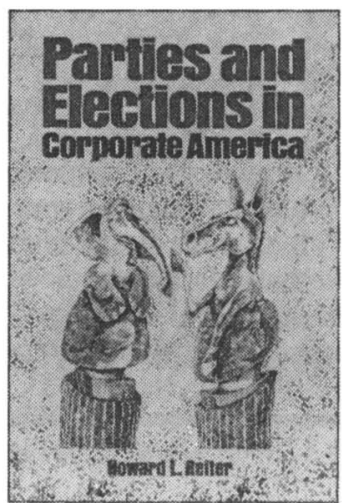

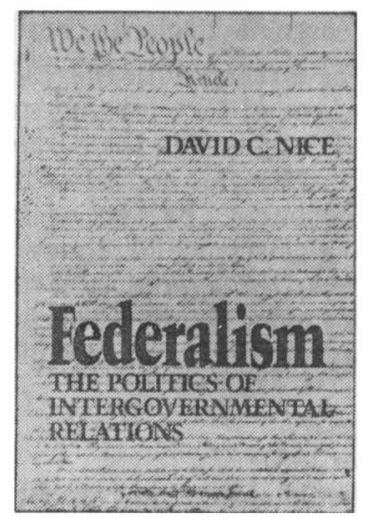

\section{Federalism \\ THE POLITICS OF INTERGOVERNMENTAL RELATIONS DAVID C. NICE, University of Georgia}

A brief but wide-ranging text that analyzes both the relationships among the national, state, and local governments in the American federal system and the ways in which individuals and groups pursue policy goals within that system. The author uses case studies to provide real-world illustrations of the interplay between levels in the federal system as well as presenting and evaluating various theoretical models of how this system works.

Paperbound. 226 pages. 1987

\section{Parties and Elections in Corporate America} HOWARD L. REITER, University of Connecticut

Written from a provocative, radical perspective, this comprehensive textbook emphasizes the place of parties in the broader social and economic context of corporate capitalism. The author offers unique coverage of the rationale for political parties and the differences between the Republican and Democratic parties.

384 pages. 1987 


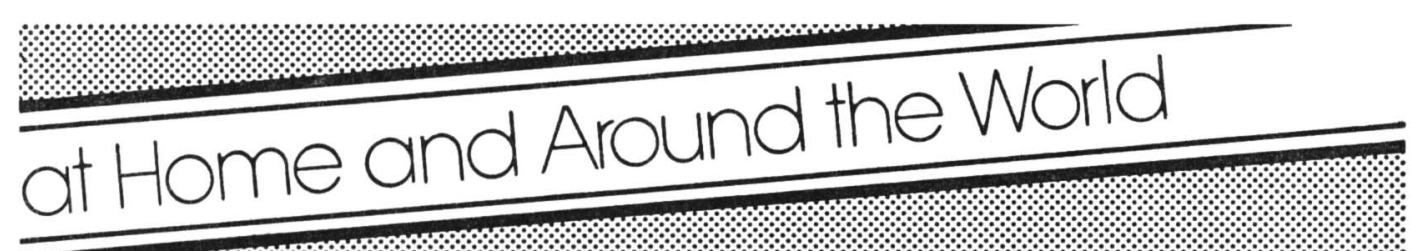

\section{At Issue POLITICS IN THE WORLD ARENA Fifth Edition \\ Edited by STEVEN L. SPIEGEL, University of California, Los Angeles}

An anthology of 35 articles, 32 of them new to this edition, that explore current issues in world politics. Opposing viewpoints are offered on several controversial issues, including arms control and Nicaragua. All of the articles are by experts or wellknown writers in the field.

Paperbound. 560 pages (probable).

Publication: November 1987

Prepublication examination copies now available

\section{Soviet Politics CONTINUITY AND CONTRADICTION} GORDON B. SMITH, University of South Carolina

Comprehensive and up-to-date, this analysis of the formal and informal forces that shape the Soviet political system illustrates the continuities and contradictions that have consistently pervaded that system. Drawing on his extensive experience in the Soviet Union, the author provides detailed discussion of policy areas such as local politics, the arts, science, technology, education, religion, and dissent as well as coverage of the 27 th Party Congress and the first year of the Gorbachev regime.

Paperbound. 400 pages.

Publication: November 1987

Prepublication examination copies now available
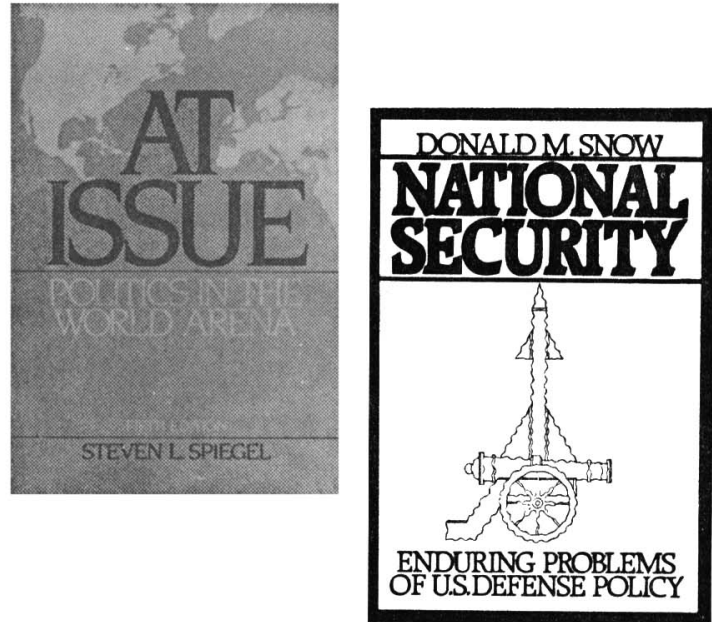

\section{National Security ENDURING PROBLEMS OF} U.S. DEFENSE POLICY

DONALD M. SNOW, University of Alabama

A concise, nontheoretical analysis of the need for national defense that examines the evolution of our security policy from conventional to nuclear forces. The text provides a rationale for military strength as a basis of national security and then summarizes debates over national policy and the issues of nuclear deterrence and arms control.

Paperbound. 272 pages. 1987

To request an examination copy of any of these titles, please write to us on your college letterhead, specifying the title of your course, present text, and approximate enrollment. Send your request to:

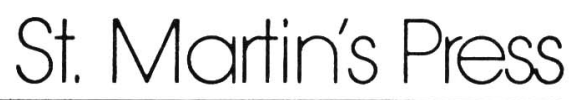




\section{AUBURN HOUSE}

\section{Child Care}

Facing the Hard Choices

Alfred J. Kahn and Sheila B. Kamerman

273 pages / $\$ 26.00$ cloth

Financing Health Care

Economic Efficiency and Equity

Steven R. Eastaugh

720 pages / $\$ 34.95$ cloth / $\$ 17.95$ paper

Student Loans

Risks and Realities

Joseph Marr Cronin and Sylvia Quarles Simmons, Editors

200 pages / $\$ 24.95$ cloth

\section{Unions in Crisis and Beyond}

Perspectives from Six Countries

Richard Edwards, Paolo Garonna, and Franz Todtling, Editors

340 pages / $\$ 35.00$ cloth

\section{China and the Third World}

Champion or Challenger?

Lillian Craig Harris and Robert L. Worden, Editors

174 pages / $\$ 29.00$ cloth

\section{The Defense of Western Europe}

Lewis H. Gann, Editor

320 pages / $\$ 32.50$ cloth

Securing Europe's Future

Changing Elements of European Security

Stephen J. Flanagan and Fen Osler Hampson, Editors

336 pages / $\$ 32.50$ cloth

The Soviet Far East Military Buildup

Nuclear Dilemmas and Asian Security

Richard H. Solomon and Masataka Kosaka, Editors 301 pages / $\$ 29.95$ cloth / \$16.95 paper 


\section{New from Cambridge University Press}

\section{The Political Economy of Central America since 1920}

Victor Bulmer-Thomas

Explores economic and social development in the five Central American republics from 1920 to the present. Examines the variations in economic policy between the countries, which helps to account for differences in performance. Major political developments are linked to internal and external changes.

Hardcover about $\$ 39.50 \quad$ Paperback about $\$ 12.95$

\section{Political Parties}

Organisation and Power

Angelo Panebianco

Marc Silver, Translator

"... an excellent study of political parties, combining historical data and theoretical analysis in a manner rarely found." - Peter Lange, Duke University

Hardcover about $\$ 54.50$ Paperback about $\$ 16.95$

\section{Human Rights and International Relations}

\section{R.J. Vincent}

About the impact of human rights on the relations among states in which Vincent recommends that provision for subsistence rights has a strong claim to priority over other human rights.

Hardcover $\$ 34.50$ Paperback $\$ 8.95$

\section{Germany Between East and West \\ Edwina Moreton, Editor}

Examines the contemporary role of Germany in international politics, and shows how the German question will continue to affect east-west relations and the politics of the western alliance in the future.

About $\$ 37.50$

\section{Disabled Policy}

America's Programs for the Handicapped

A Twentieth-Century Fund Report

\section{Edward D. Berkowitz}

"...An extremely thoughtful and persuasive history of disability policy in America... must reading for all those interested in programs for the handicapped, social welfare history, and public policy-making in America." - Walter I. Trattner, University of Wisconsin, Milwaukee $\$ 24.95$

\section{The Field of Social Investment}

\section{Severyn T. Bruyn}

"This is a work reflecting much current interest and concern. I've read it with real advantage; so, I am sure, will others who are concerned with corporate government and its social effects."

\section{- John Kenneth Galbraith, Harvard University}

$\$ 34.50$

\section{At bookstores or order from \\ Cambridge University Press}

32 East 57th Street, NY, NY 10022.

Cambridge Toll-free numbers for orders only:

800-872-7423, outside NY State. 800-227-0247, NY State only.

MasterCard and Visa accepted. 


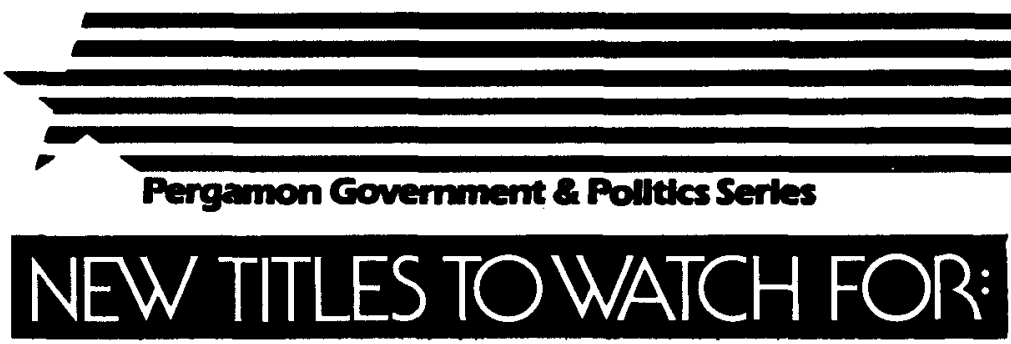

\section{THE PRESIDENTIAL BRANCH}

\section{John Hart, Australian National University}

"By providing a deep historical and a broad contextual analysis of THE PRESIDENTIAL BRANCH. Hart's outstanding book gives us exactly what we need to place the Iran-Contra affair in perspective. Its scholarship is as good as its timing." Aoron W/ldovsky, Univensity of Collfornia, Berkeley

In this original study, Professor Hart traces the history of the White House office from the development of a rudimentary staff system in 1789, through the suggested reforms of 1937. He then follows the fluctuations in size and power of the cabinet, the impact of Watergate and post-Wotergate presidencies, and analyzes the nature and form of congressionol oversight. In conclusion, the author assesses reform proposals that hove been generated during the last decade, and discusses the ambivalent position of the Presidential branch in the structure of American government.

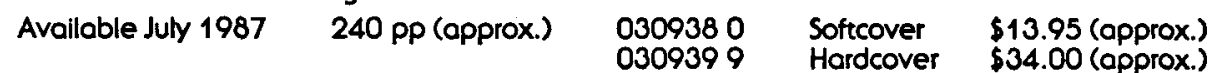

\section{BUREAUCRATIC DISCRETION: Low and Policy in Federal Regulatory Agencies}

Gary C. Bryner, Brigham Young University

"Gary Bryner speoks on the federal regulatory process with one of today's most authoritative scholarty voices. This is a timely book on a topic that is already hotly controversiol and will become more so. and all parties to the debate will find his views wise and insightful." James L. Sundquist, The Brookings Institution

Through four case studies-based on interviews with agency officials, documents, and other materials-different methods of bureaucratic regulation are explored, Including administrative law, scientific and technical policy analysis, and congressional oversight. The author concludes with a discussion of the kinds of efforts thot can direct and limit administrative discretion and at the same time contribute to the ability of agencies to accomplish the policy tasks delegated to them.

Available June 1987

$$
240 \text { pp (opprox.) }
$$

0344933 0344941

Softcover

\section{THE POLITICS OF FEDERAL REORGANIZATION: Creating the Department of Education}

Beryl A. Radin, University of Southern Californio Public Policy Center, Washington, DC, and Willis D. Hawley, Vanderbilt University, Nashville, TN The realization of the federal Department of Education illustrates a series of complicated actions relating to policy implementation and presidential use of power. Authors Radin and Hawley unravel mony polltical themes and motives which underlie the formation of a new govemment department in general and the issues specific to the Carter administration. The politics of the executive branch, as well os bureaucratic response to change, are examined in depth, using the cose study of the Department of Educotion to follow a policy proposal through the multiple forms and arenas for decision making. where each stage creates new opportunities and imposes new sets of constraints.
Avallable August 1987
225 pp. (opprox.)
0339778
Softcover
$\$ 12.95$ (opprox.) 0339786 Hardcover $\$ 29.50$ (opprox.) 


\section{With the Presidential election}

just around the corner, where can you

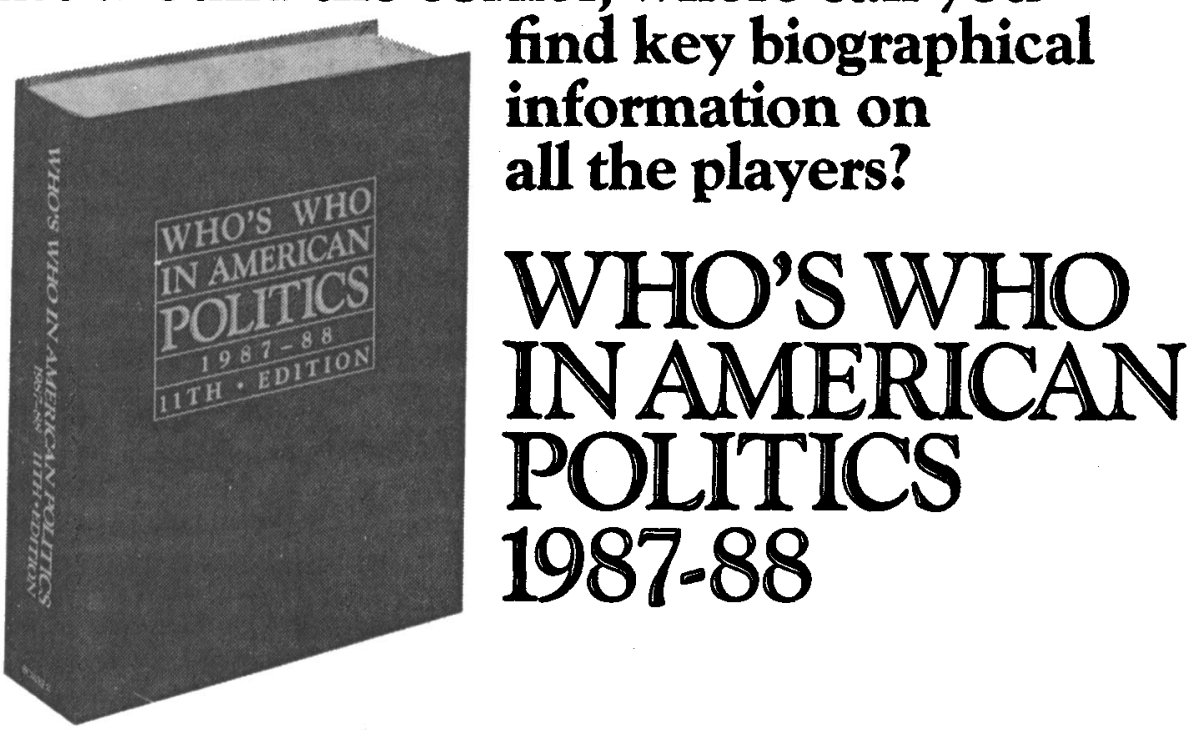

Who's Who in American Politics provides complete biographical information on each of 23,814 men and women currently active in politics at every level. Each individual's concise, informative entry will show you offices held, books and articles written, educational background, current mailing address, and much more.

There's simply no better way to locate up-to-date information about federal, state, and local politicians and other policy-makers throughout the U.S. and its territories.

Whos' Who in American Politics can help you:

write articles

answer reference questions

- carry out research and consulting projects

- introduce speakers
- campaign
work on government projects
- and answer a broad range of political inquiries

Who's Who in American Politics is available exclusively from R. R. Bowker, so order your copy today. Our customer service representatives are standing by to take your order. Better yet, place a standing order and receive this edition and all subsequent editions with a $5 \%$ discount automatically deducted.

Who's Who in American Politics

0-8352-2219-5 Sept. 1987 1,800 pp. cloth Published every two years.

$\$ 149.95$ Standing Order Price $\$ 142.45$

To Order Toll Free: 1-800-521-8110

In NY, AK or HI: Call Collect: 1-212-337-6934

In Canada Call Toll Free: 1-800-537-8416

Prices are applicable in the U.S., its territories, and in Canada. All invoices are payable in U.S. dollars. Prices and publication dates are subject to change withour noxice. Applicable sales rax must be included. Except as noted, shipping and handling will be added to each order at the following rate: $5 \%$ of the net invoice amount, excluding tax. Minimum shipping and handling charge: \$3.50. U.S. Telex: 12-7703. U.S. Fax: 1-212-337-7157. Please allow 4-6 weeks for delivery by Book Rate or Library Rate. Rest of world: R.R. Bowker (U.K.) Lid., P.O. Box 88, Borough Green, Kent TN15 8PH, England. Telex: 95678 . Fax: 0732

R.R. BOWKER THE INFORMATION REFERENCE
COMPANY 884079 . 


\section{Announcing 5 Instructional Units On Comparative Politics}

\section{with print and audio components}

Each unit consists of a monograph and 60 minute audio cassette that provides a comparative perspective on a specific topic taught in courses on American government and politics. A unit can be used singly or in combination with others in the series in order to introduce students to other countries' institutions and policies. The units can be adapted for an introductory American government and politics course or for upper division courses.

The Administrative State in Industrialized Democracies by Joel $D$. Aberbach and Bert A. Rockman

\section{Coordinating International Economic} Strategy

by Stephen Cohen and John Zysman

\section{Comparative Political Parties \\ by William Crotty}

\section{The Welfare State in Hard Times}

by Hugh Heclo

\section{Preserving Peace: The Difficult} Choice of International Security

by George H. Quester

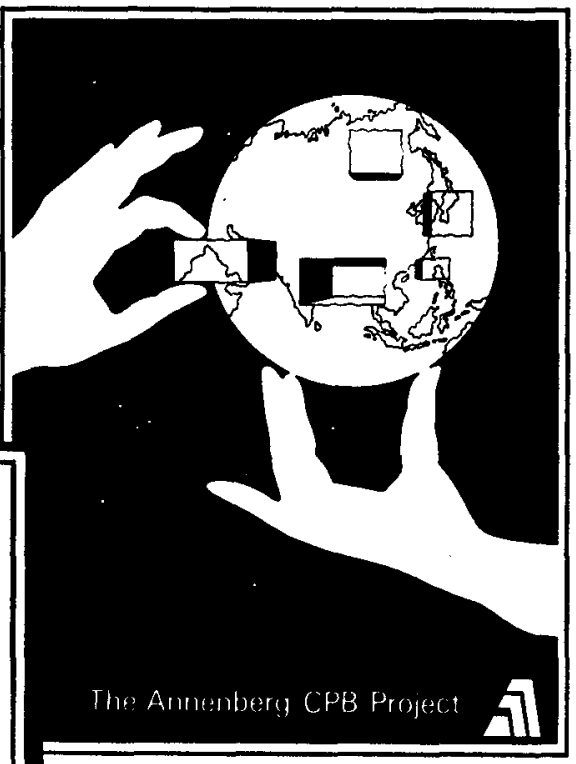

Each monograph includes an essay, a bibliography and notes for the instructor.

Each cassette dramatizes the issues in the monograph through interviews with scholars and political leaders and citizens in other countries.

This series is based on material from two audio/print college courses entitled, "Global Understanding," developed and produced by National Public Radio, in conjunction with the University of California at San Diego and

Columbia University, New York.

The Annenberg/CPB Project supported the development of these units.

The units are $\$ 4.50$ per copy with a $20 \%$ discount for orders of 20 or more. Twenty copies of a title are accompanied by the audio cassette at no charge.

To order, write to:

The American Political Science Association 1527 New Hampshire Avenue, N.W., Washington, D.C. 20036 


\section{The ins and outs of government-from Johns Hopkins}

\section{The In-and-Outers}

Presidential Appointees and Transient Government in Washington edited by G. Calvin Mackenzie

"This is must reading for anyone who wants to understand the presidential appointment power and the dynamics of executive branch leadership."

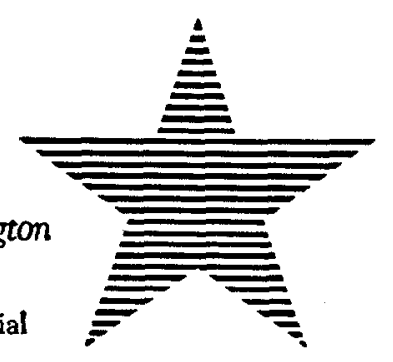

-Thomas E. Cronin, Colorado College

Known in the federal bureaucracy as "in-and-outers," presidential appointees are individuals for whom government service is neither a profession nor a career. The In-and-Onters offers unprecedented insights into the presidential appointment process; the backgrounds, work lives, satisfactions, and frustrations of the appointees themselves; and such issues as conflict of interest, Senate confirmation, and postemployment experiences. $\$ 26.50$

In Paperback

\section{The Confidence Gap}

Business, Labor, and Govemment in the Public Mind REVISED EDITION

Seymour Martin Lipset and William Schneider

"Lipset and Schneider adeptly organize and supplement the findings of the many studies that have examined the low levels of trust and confidence in American institutions, and they offer their own provocative conclusions."

-Robert Y. Shapiro, Political Science Quarterly

Now in paperback - with additions and revisions that incorporate data through 1986-The Confidence Gap provides a sweeping analysis of Americans' changing perceptions of their institutions, their leaders, and their country. $\$ 14.95$

\section{In Paperbuck}

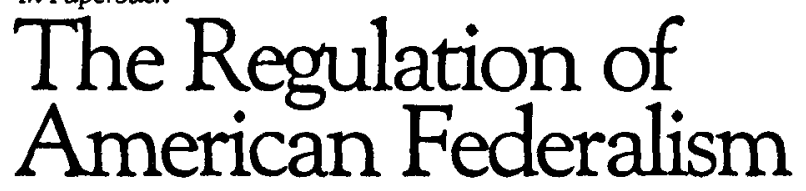

\section{Donald F. Kettl}

"[The book] should be required reading for all students of contemporary federalism. ... [It] is both wise and exceptionally well written." - Diane D. Blair, Joumal of Politics

Now in paperback with a new epilogue on the Reagan years, The Regulation of American Federalism explores the intricate relationships and political conflicts that have transformed American federalism into a regulatory arena dominated by the central government. $\$ \mathbf{8 . 9 5}$ 
Three new titles in

Studies in International Political Economy

Stephen D. Krasner, Editor

Ernesf B. Haas, Consulting Editor

\section{THE POWER} OF

\section{IDEOLOGY}

The Quest for Technological Autonomy in Argentina and Brazil

\section{EMANUEL ADLER}

Adler addresses the hotly contested issue of how developing nations can emerge from the economic and technological tutelage of the developed world.

"A very significant contribution to our understanding of a suprisingly broad range of scholarly issues now widely debated."

$\$ 45.00$ cloth
- Robert C. North, Stanford University
BANKER TO THE THIRD WORLD

U.S. Portfolio Investment in Latin America, 1900-1986

\section{BARBARA STALLINGS}

"In the the flood of books on the Third World debt crisis, Barbara Stalling's volume stands out for its historical perspective, useful collection of data. sound economic analysis and cool understanding. ...An excellent contribution!"

-Charles P. Kindleberger, author of The World in Depression

"The book will be read and reread by any serious student of 20 th century international economy and politics." - Michael Edelstein $\$ 45.00$ cloth, $\$ 12.95$ paper
RULING THE WAVES

The Political Economy of International Shipping ALAN W. CAFRUNY "This work takes a central question of political economy a stage further by a detailed and masterly analysis of the political economy of world shipping."

- Susan Strange, London

School of Economics and Political Science

"The most thorough study of how and why the international shipping industry has evolved along certain lines. It provides a very insightful analysis of how the policies and power of the Western nations, whose interests were often quite divergent, shaped the character of the industry and certain 'rules of the game'."

- Mark Zacher, co-author of Pollution, Politics, and $\$ 40.00$ cloth International Law

At bookstores or call toll-free 800-822-6657. Visa and MasterCard only.

University of California Press

Berkeley 94720 


\section{Three new titles in the California Series on Social Choice and Political Economy}

Brian Barry, Robert H. Bates and Samuel L. Popkin, Editors

\section{POLITICAL}

\section{SURVIVAL}

Politicians and

Public Policy in

Latin America

\section{BARRY AMES}

"Political Survival is that rarest of books in compar-

ative politics: a theoreti-

cally innovative work with

an empirical, cross-

national focus....A good

read. 'Raises the ante' in

comparative studies of

public policy by bringing

sophisticated, systematic

thinking to the analysis of

decision-making in the

Third World."

-Peter McDonough.

$\$ 38.00$ cloth

University of Michigan

\section{THE \\ CAUSAL THEORY OF JUSTICE KAROL EDWARD SOLTAN}

Soltan provides an

exciting, original, and fresh examination of the issue of justice.

"A fine work on the theory of justice and liberal

thought. The writing is bold and clear. The framework of the argument goes

together as though made of structural steel."

- Charles W. Anderson. University of Wisconsin $\$ 30.00$ cloth
PRINCIPLES OF GROUP SOLIDARITY MICHAEL HECHTER

"An important contribution to our understanding of group action and solidarity."

-Douglass C. North, Washington University "A very important book. It is, by far, the clearest and most forceful effort in this area.... It should and will be read by all social theorists."

- Jonathan Turner, University of California, $\$ 28.50$ cloth

\section{THE STATISTICAL ANALYSIS OF QUASI- EXPERIMENTS}

\section{CHRISTOPHER H. ACHEN}

Contemporary social science makes routine use of statistical methods. However, the quantitative techniques were originally developed for natural science applications. and they make strong assumptions. Achen explains why quasi-experiments are inevitable and why conventional statistical analysis of them has failed. $\$ 32.00$ cloth 


\title{
$\mathrm{HBJ}$ \\ COMMUNIQUE \\ ․ㅡㄹ
}

\section{HBJ Political Science: Exciting choices for 1988}

\author{
PUBLIC \\ POLICY \\ IN AMERICA

\section{DENNIS J. PALUMBO \\ Hardcover. 416 pages. \\ JUST PUBLISHED.}

Government in Action

\section{AMERICAN CONSTITUTIONAL Essays and Cases Essays and Cases}

\section{AMERICAN JUDICIAL POLITICS}

A comprehensive basic textbook for courses in public policy, PUBLIC POLICY IN AMERICA features an innovative two-part organization for fuller, clearer coverage of both policy making and policy issues. Part I describes the various stages of the policy cycle. Part II covers how the policy cycle is applied to specific issues.

OTIS H. STEPHENS, JR., AND JOHN M. SCHEB, II Hardcover. 992 pages (tent.) 1988 These two distinguished authors and scholars have written a major new text for the constitutional law course. They offer comprehensive introductory essays, a broad selection of cases, substantial excerpts, and extensive coverage of all major constitutional topics current through 1987. The text offers more attention to property rights and economic issues than competing texts do.

\section{HARRY P. STUMPF}

Hardcover. 512 pages

JUST PUBLISHED.

AMERICAN JUDICIAL POLITICS is a new text intended for courses in judicial process, judicial politics, and law in society. It offers coverage of the entire field of judicial politics with discussion of every major subtopic. Emphasis is on the jurisprudential grounding of the field. 


\title{
Professions and the State: The Mexican Case
}

\author{
A PROFMEX book by Peter $S$. Cleaves
}

\begin{abstract}
This new monograph examines how a relatively foreign concept, professionalism, is superimposed on cultural, historical, and political patterns in Mexico, and considers conflicts affecting professional nationalism, university training, unemployment, prestige, and public policy-making. Cleaves' study focuses on the self-images of the professions in historical and political context and on the way in which the professions and the state seek to influence one another. While lawyers have traditionally held positions of considerable political influence, members of other professions-agronomists, engineers, physicians, and economists-are now vying for power and gradually displacing lawyers in the upper echelons of power. Cleaves describes the possible changes this trend may bring about in the way the state manages potentially disruptive economic and social pressures. 175 pages, \$19.95.
\end{abstract}

\section{The University of Arizona Press 1230 N. Park, \#102, Tucson, AZ 85719}

New! DENIAL OF EXISTENCE: Essays on the Human Condition by Brij Mohan. This stimulating and thought-provoking work conceptualizes the human condition, examines oppression and the need for social development, and offers a new perspective on existential intervention. The author also explores the relationship between human behavior and social policy, aspects of human aggressiveness from family violence to nuclear war, the necessity for critical assessment of human conditions, and the ultimate relevance of peace and justice. ' $87, \$ 19.50$

THE ECONOMICS OF PROSTITUTION by Helen Reynolds. Starting from the premise that it will exist regardless of its legal status, the author provides an economist's perspective of prostitution. She applies incentive/disincentive principles and identifies the types of environments in which prostitution exists in the U.S. Analyses and recommendations for government officials conclude the text. ' $85, \$ 27.25$

\section{THE IMPACT OF SOCIAL PSYCHOLOGY ON} PROCEDURAL JUSTICE edited by Martin F. Kaplan. This volume reports on applications of social science to legal systems, policies and practice. Noted authorities on the interface between law and psychology describe pertinent research and show how it has been used to improve trial conduct and relevant legal policies. Among the areas thus examined are substantive contributions to federal court policy and procedures, eyewitness research, voir dire, trial consultation, jury instructions and sentencing. ' $86, \$ 32.50$

THE RIGHT TO KEEP AND BEAR ARMS: A Continuing American Dilemma by Earl R. Kruschke. Ongoing controversies surrounding the right to bear arms receive clear and thoughtful explication in this text. The author probes both the collective and individual sides of the issues, and he excerpts judicial opinions that support both viewpoints. He also proposes possible solutions to the dilemma. ' $85, \$ 27.00$

Order direct for fastest results • Write or call (217) 789-8980 • Books sent on approval MasterCard, Visa \& prepaid orders sent postpaid $\bullet$ Catalog sent on request

CHARLES C THOMAS • PUBLISHER 2600 South First Street • Springfield • Illinois • $62794-9265$ 
SCIENCE

\section{in American Politics}

\section{Elections}

Voting Behavior: The 1984 Election by Charles Prysby and Carmine Scavo Campaign '80: The Public and the Presidential Selection Process

Polifical Behavior and Institutions by Richard Joslyn and Janet Johnson

Elections and the Mass Media

by David Blomquist

Political Socialization Across the Generations

by Paul Allen Beck, Jere Bruner and L. Douglas Dobson

Presidential Popularity in America

by Stephen Frantzich

The Dynamics of Political Budgeting

by Marvin K. Hoffman

The Supreme Col if 'out merican Politics, 2nd ed.

John Paul Ryan SOLW. Neal Tate

Policy Strain and Fiscal Responsiveness in

51 American Communities

by Paul David Schumaker, Russell W. Getter and Terry Nichols Clark

A SETUPS monograph includes a descriptive essay; instructions on methods of anaylsis; exercises based upon a data set; the code book for a data set and a bibliography. The data set is provided, at no charge, when $\mathbf{2 5}$ or more SETUPS are ordered.

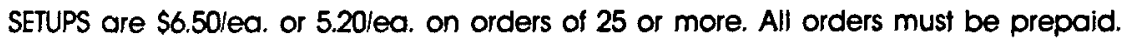
Write for a price list, with shipping charges to: 


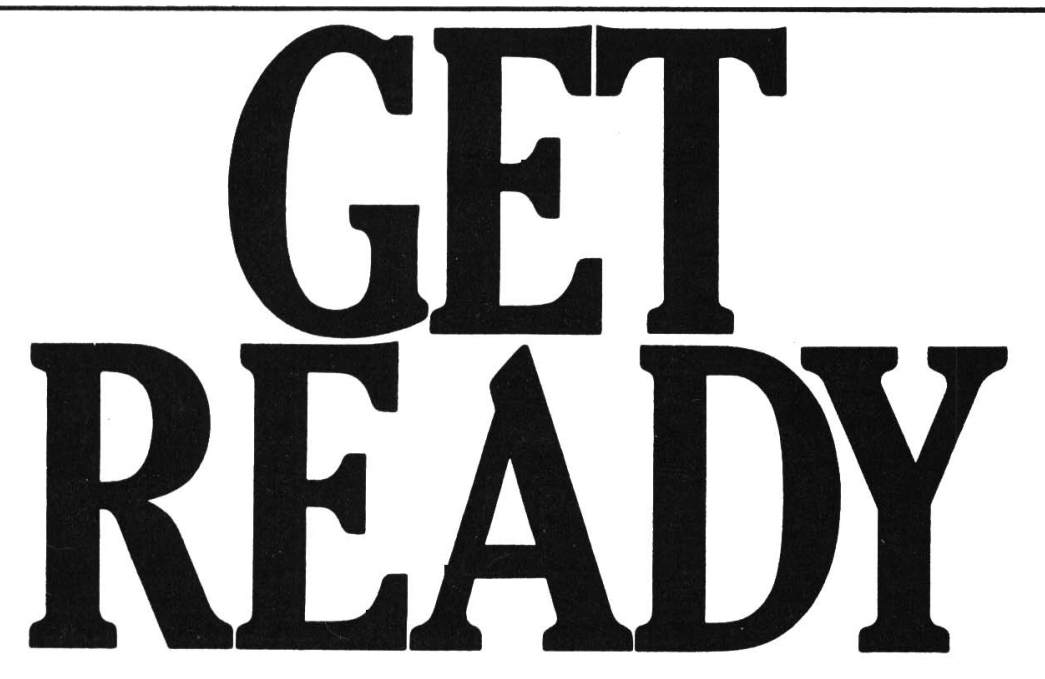

\section{$\because$ FOR NEW SPSS} SOFTWARE.

- SPSS-X Release 3 - featuring expanded statistics and end-use. facilities

- Time series analysis for both SPSS-X and SPSS/PC+
- FOR NEW SPSS PUBLICATIONS.

\section{- SPSS-X Release 3 editions of:} SPSS-X User's Guide SPSS- $X$ Introductory Statistics Guide SPSS-X Advanced Statistics Guide SPSS- $X$ Tables"
SPSS data analysis software systems and publications for mainframe, mini and micro computers are used in thousands of academic environme around the world. For teaching. learning and conducting research in a variety of disciplines including mare. Besides our, science and released products, here are a few of the many titles available now.

\section{SPSS-X" USERS GUIDE}

Second Edition

SPSS Inc. 1985 (918469-18-X)

988 pages - softcover

Designed to be both a guide and reference text, this manual

contains full documentation for

SPSS-X INTRODUCTORY

STATISTICS GUIDE

Marija J. Norusis

1983 (0-07-046549-5)

276 pages - softcover

A review of basic statistics and how

to calculate them with SPSS- $x$,

including descriptive statistics,

hypothesis testing. nonparametric

procedures, correlation, analysis of

variance and regression. With

numerous output examples and

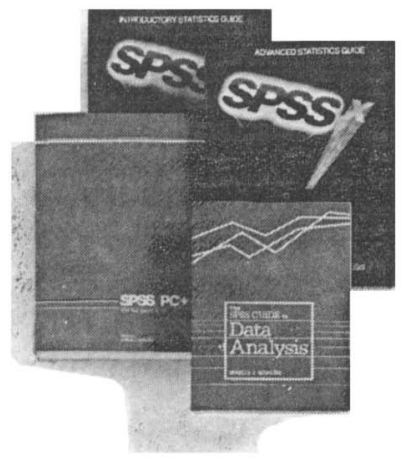

THE SPSS GUIDE TO DATA ANALYSIS

Marija J. Norusis

1986 (918469-24-4)

402 pages - sottcover

An introduction to the research

process from questionnaire design

and sample selection through

data analysis. Free supplementary

diskette (avallable for textbook

health and social science
SPSS-X ADVANCED

STATISTICS GUIDE

Marija J. Norusis

432 pages - sottco

A soltware reference for researchers and a text for the multivariate

statistics course. Explains statistical concepts and SPSS-X procedures for factor, discriminant, cluster and loglinear analysis as well as multivariate analysis of variance. Includes exercises and an appendix that reviews basic operations.

\section{SPSS/PC+ PUBLICATIONS}

Publications available for the SPSS/PC+"' family of software basic guide and reference to SPSS/PC+, SPSS/PC+ Advanced Statistics", SPSS/PC+ Tables" and SPSS/PC+ Data Entry".

To order SPSS publications or find out more about our soon-to-be released products,

CALL1/312/329-3327 


\section{ANNOUNCING A NEW AMERICAN GOVERNMENT PAPERBACK TEXT.}

\section{American Government}

Alan Gitelson, Loyola University

Robert Dudley, George Mason University

Melvin Dubnick, University of Kansas

About 450 pages - paperback • Instructor's

Manual - Test Bank - Study Guide - Transparencies - MicroStudy Plus: Computerized Study Guide - LectureBank: Computerized Lecture Outlines - MicroTest: Computerized Test Bank • Call-in Test Service • GPA: Grade Performance Analyzer - December 1987

Gitelson, Dudley, and Dubnick's new paperback text uncovers essential topics in American government through a unique format. Each chapter opens by discussing a common myth in American politics-for example, that of the all-powerful president. Students then discover basic facts about government and the role myths play in our understanding of political events.

Also of Interest...

The Challenge of Democracy:

Government in America

Kenneth Janda, Northwestern University Jeffrey M. Berry, Tufts University Jerry Goldman, Northwestern University

NEW

Public Administration:

Concepts and Cases

Fourth Edition

Richard J. Stillman, II

George Mason University

\section{Global Politics, Third Edition}

James Lee Ray, Florida State University

For adoption consideration, request examination copies from your regional Houghton Mifflin office.

\section{Houghton Mifflin}

13400 Midway Rd., Dallas, TX 75244-5165

1900 S. Batavia Ave., Geneva, IL 60134

989 Lenox Dr., Lawrenceville, NJ 08648

925 E. Meadow Dr., Palo Alto, CA 94303 


\title{
Guides to understanding the issues of church and state... new from Macmillan
}

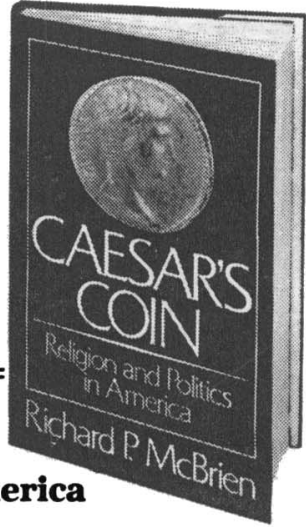

\section{Caesar's Coin Religion and Politics in America}

RICHARD P. MCBRIEN

Richard McBrien goes right to the heart of the passionate debate: from abortion rights and gay rights to school prayer and the new political clout of the clergy, he tackles controversies and gives us a valuable new primer about the role and limits of religion in public life.
"Anyone interested in the fundamental questions of church and state, religion and politics, morality and government, will welcome [this] intelligent, clear treatment."-Mario Cuomo "....a work of exact, prudent scholarship...thoughtful and excellent."-America

ISBN 0-02-919720-1 $\$ 19.95$

\section{The Catholic Challenge to the American Economy}

\author{
Reflections on the U.S. Bishops' Pastoral Letter on Catholic Social \\ Teaching and the U.S. Economy \\ Editor: THOMAS M. GANNON, S.J.
} The Bishops' Letter is both a critique of policies that work against the needs of the poor, unemployed, homeless, and oppressed, and a new agenda for peace and economic justice. Here, in 18 original essays, is the first analysis of its meaning and significance. Contribu-

tors include economist Milton Friedman, theologian Charles E. Curran, sociologist Norman Birnbaum, and Sen. Albert Gore, Jr. Includes the complete text of the letter. " $A$ much needed and thorough evaluation, from many points of view." - Leon $\mathrm{H}$. Keyserling

ISBN 0-02-911260-5 •\$24.95 ISBN 0-02-911270-2 • \$14.95, paper

\section{The Believer and the Powers That Are}

\section{Cases, History, and Other Data Bearing on the Relation of Religion and} Government

Editor: JOHN T. NOONAN, Jr.

This remarkable sourcebook contains nearly 200 documents from the changing course of church-state relations throughout history, ranging from Biblical passages to recent Supreme Court cases. Divided into three sections"Roots," "The American Experience," and "Contemporary Controversies"-

the material includes letters, speeches, manifestos, legislation, and cases, each placed in context with extensive notes by the editor, who provides many fresh, first-time translations. Incisive introductions and commentary provide the historical settings and raise important critical questions.

ISBN 0-02-923161-2 $\$ 35.00$

\author{
MACMILLAN PUBLISHING COMPANY \\ 866 THIRD AVENUE • NEW YORK, NY 10022 • ATT: KAREN STAUBI
}




\section{Hard Judicial Choices}

\section{Federal District Court Judges and State and Local Officials}

PHILLIP J. COOPER, State University of New York, Albany

In controversial court cases involving civil rights, schools and housing, prison reform, and other social issues, federal district-court judges are often called upon to make some of the most difficult judicial decisions. How do these cases arise? How are they prosecuted and remedies fashioned when federally protected rights are violated? How can relations between federal judges and state and local officials be improved?

This book - the first to attempt to look at such cases from the district court judge's point of view-examines some of these questions through five comparative case studies involving open housing in a Cleveland suburb, school desegregation in Detroit, mental health reform in Alabama, prison conditions in Ohio, and alleged police misconduct in Philadelphia. Cooper presents a clear overview of the remedial decree process and prefaces each of the case studies with a full chapter that sets the case in its legal, administrative, and political context.

Taking a close look at the interactions between federal district court judges and state and local officials, this volume produces a model of remedial decree litigation that challenges widely-held assumptions about the role of district judges in such controversial cases.

December 1987400 pp.; 4 linecuts paper $\$ 12.95$ cloth $\$ 29.95$

Winner of the American Political Science Association's

Woodrow Wilson award for 1986

\section{Governing the Economy}

The Politics of State Intervention in Britain and France

PETER A. HALL, Harvard University

Analyzing the evolution of economic policy in postwar Britain, this book develops a striking new argument about the sources of Britain's economic problems. Through an insightful, comparative examination of policy-making in Britain and France, Hall presents a new approach to state-society relations that emphasizes the crucial role of institutional structures.

(Europe and the International Order)

1986340 pp. paper $\$ 14.95$ cloth $\$ 36.00$ 


\section{Journeys Among Women}

\section{Feminism in Five Italian Cities}

JUDITH ADLER HELLMAN, York University, Toronto

This book examines the growth of feminism in five strikingly different settings: Turin, Milan, Reggio Emilia, Verona, and Caserta. Tracing the development of the Italian women's movement from the 1960s through the 1980 s, the author focuses on the ways in which the specific social and political traditions of the five cities shape the development of a new social movement. (Europe and the International Order)

1987224 pp. paper $\$ 13.95$ cloth $\$ 39.95$

\section{The Mitterrand Experiment}

Continuity and Change in Modern France

Edited by GEORGE ROSS, Brandeis University, STANLEY HOFFMANN, Harvard University, and SYLVIA MALZACHER, Center for European Studies, Harvard University

Taking a sober, detailed look at the successes and failures of Mitterrand's Socialist government, these essays by leading international experts examine crucial topics such as the macroeconomic policies of the left, the left and the media, and the politics of the private sector.

(Europe and the International Order)

1987240 pp. paper $\$ 15.95$ cloth $\$ 39.95$

\section{Studies in Power and Class in Africa}

Edited by IRVING LEONARD MARKOVITZ, Queens College,

City University of New York

"In conceptualization and analysis, in presentation and comprehensiveness, this book is excellent for pedagogical purposes."-Alaba Ocunsanwo, Rutgers University. Unified by the basic concepts of all politics-who gets what, when, where, and why, and who gets left out-these wide-ranging essays address problems of major concern in the daily lives of African people during and after the colonial period.

1987400 pp.; 2 maps paper $\$ 14.95$ cloth $\$ 32.00$

\section{Reagan, Thatcher and the Politics of Decline \\ JOEL KRIEGER, Wellesley College}

"Joel Krieger stakes out his own position boldly, elaborating a critique of new right governance that is both emotionally charged and intellectually stimulating."-American Political Science Review. In this incisive comparative study, Krieger cogently analyzes recent trends toward conservatism in both the United States and Britain under the Reagan and Thatcher governments and assesses their impact on the future of Western democracies.

(Europe and the International Order)

1986247 pp. paper $\$ 11.95$ cloth $\$ 29.95$

\section{Oxford University Press \\ 200 Madison Avenue - New York, NY 10016}




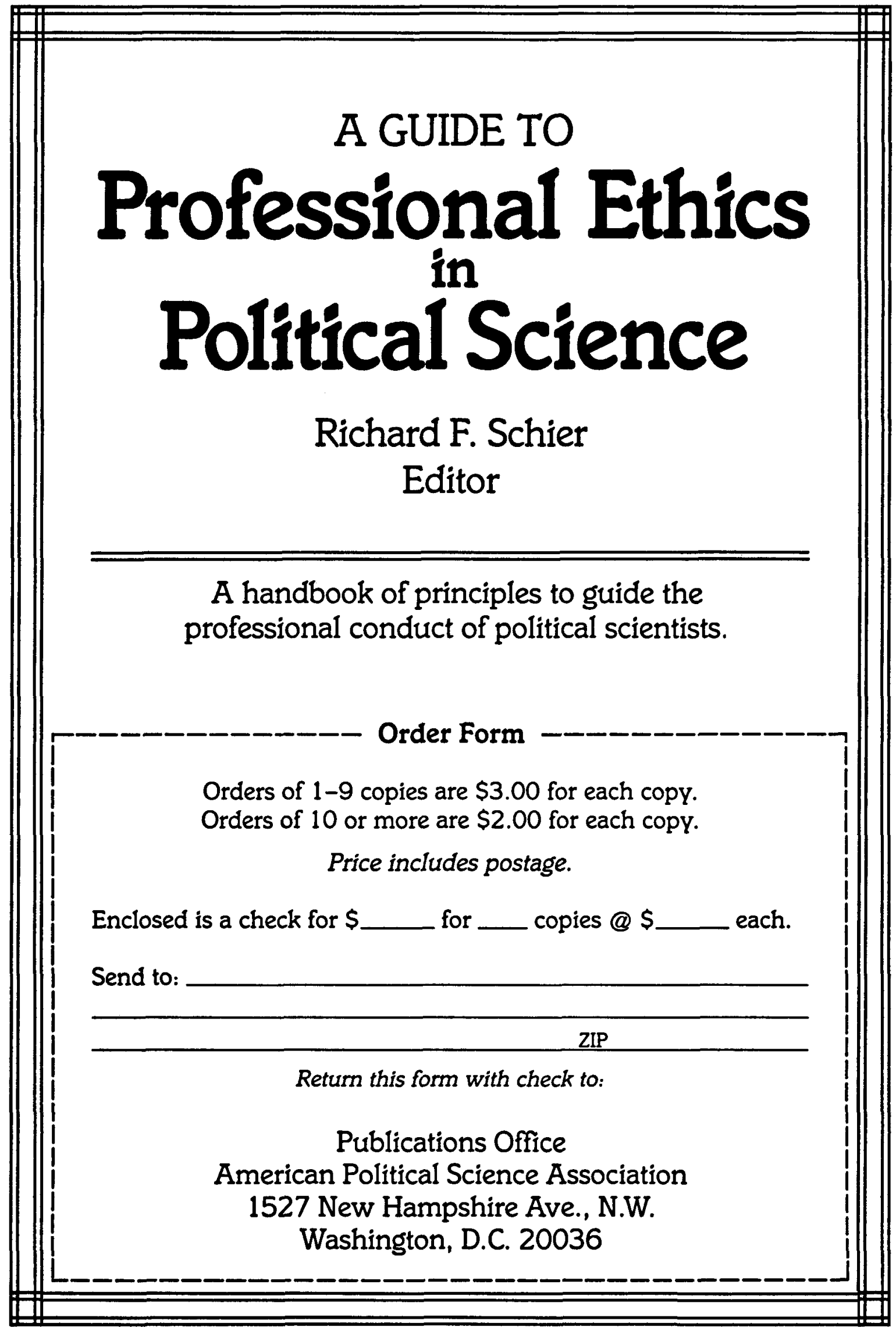


New in the POLITICAL ECONOMY OF INTERNATIONAL CHANGE Series

Trade Wars

The Theory and Practice of International Commercial Rivalry

Jobn A. C. Conybeare

Why do trade wars occur? And why do some escalate while others reach cooperative solutions?

In Trade Wars, John Conybeare applies

game-theory interpretation to actual trade wars throughout history.

352 pp., 7 graphs, 835.00
Penetrating International Markets

Theoretical Considerations and

Mexican Agriculture

David R. Mares

Using U.S.-Mexico trade as an example, Mares explains how third world entrepreneurs are able to penetrate protected markets and export to advanced industrialized countries.

296 pp., $\$ 35.00$

\section{POWER AND PRODUCTION}

A remarkably original four-volume study considering power relations in societies and in world politics from the standpoint of the social relations of production.

Production, Power, and World Order

Social Forces in the Making of History Robert W. Cax

Offers a new approach to the study of power by identifying the connections between production, the state, and world order. Cox classifies world production not by country, but rather by patterns of production relations.

392 pp., $\$ 45.00$

\section{Space Resources}

Breaking the Bonds of Earth

Jobn S. Lewis and Rutb A. Lewis

"A crisp, hard-hitting account of our present

difficulties in space, backed by a history of how we got here, and of contrasts with what the Russians are doing. It describes in an exciting way the new technologies and new resources which can start us moving forward again."-James R. Arnold, Director, California Space Institute

384 pp., photos, graphs, $\$ 30.00$

\section{The Politics of}

\section{Environmental Mediation}

Douglas J. Amy

Environmental mediation-is it politically neutral? Will it supplant litigation as a means for resolving disputes? Here Douglas Amy looks at the promise and the pitfalls of this new method.

$288 \mathrm{pp}$., $\$ 30.00$

\section{Under the Shadow of War}

Fascism, Anti-Fascism, and Marxists, 1918-1939

\section{Iarry Ceplair}

Charts the rise of Fascism in Italy and Germany, and the failures of the left to impede it. Ceplair adds significantly to our understanding of Fascism and anti-Fascism, providing crucial insights on the interwar period.

$272 \mathrm{pp}$., $\mathbf{3 2 . 5 0}$

\section{Datawars}

The Politics of Modeling in Federal Policymaking Kewnetb L. Kraemer, Siegfried Dickboven, Susan Fallows Tierney, and Jobn Leslie King Computer models are fast becoming a permanent feature of American policymaking, but, as Datawars demonstrates, they can be potent instruments of politics and power.

Computing, Organizations, Policy and Soctety (CORPS)

$326 \mathrm{pp}$., tables, figures, $\$ 35.00$
Power, Production, and the Unprotected Worker Jeffrey Harrod

An innovative approach to the questions of social and economic power, particularly as they apply to those at the lowest reaches of a production hierarchy. $336 \mathrm{pp}$. $\$ 40.00$
Now in paperback

Still the Golden Door

The Third World Comes to America

David M. Reimers

319 pp., $\$ 14.50 \mathrm{pa}$

Rosa Luxemburg

A Revolutionary for Our Times

Stepben Eric Bromer

A Morningside Book

$130 \mathrm{pp}$., $\$ 10.00 \mathrm{pa}, \$ 25.00 \mathrm{cl}$

Economic Security and the Origins of the Cold War, 1945-1950

Robert A. Pollard

The Political Economy of International Cbange

Jobn Gerard Ruggie, General Editor

$378 \mathrm{pp}$., $\$ 14.50 \mathrm{pa}$

A Cboice Outstanding Academic Book

In Pursuit of Power

Southern Blacks and Electoral Politics, 1965-1982

\section{Steven $\mathrm{F}$ Lauson}

Contemporary American History

William E. Leucbtenburg, General Editor

$391 \mathrm{pp} ., \$ 14.50 \mathrm{pa}$

\section{TAKE ACTION.}

Send check or money order, including $\$ 3.00$ for postage and handling to:

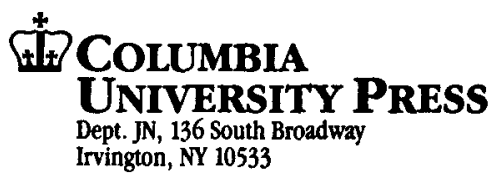




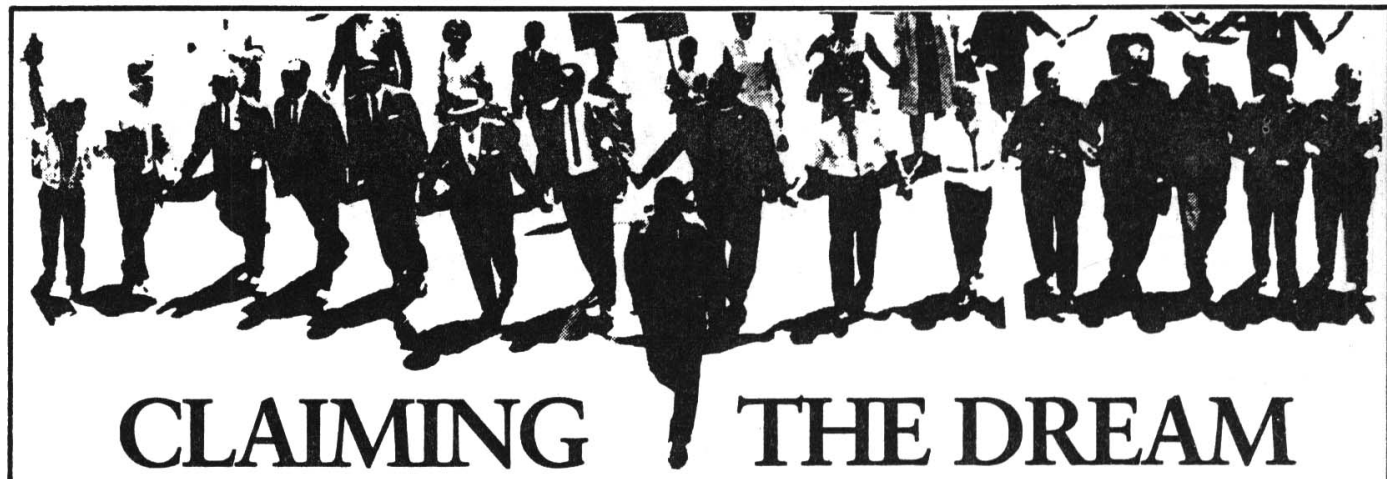

To Redeem the Soul of America

The Southern Christian Leadership Conference and Martin Luther King, Jr.

\section{Adam Fairclough}

Peering beyond the towering figure of Martin Luther King, Jr., to reveal the full workings of the organization that supported him, Adam Fairclough examines the role of such strong-willed strategists as Andrew Young, James Bevel, and Wyatt Walker in building a bridge from the black proletariat to the halls of Congress and the White House.

Illustrated \$35.00 cloth; \$17.95 paper

\section{Cause at Heart}

\section{A Former Communist Remembers}

Junius Scales and Richard Nickson

Foreword by Telford Taylor

A memoir by the only American ever convicted under the Smith Act of 1940, Cause at Heart provides a rare, candid look at the Communist Party in America during its most embattled years.

"A powerful indictment both of economic and racial injustice in the twentieth-century South and of a radical organization more concerned about the Soviet Union than about the problems and aspirations of the American working class"-Georgia Historical Quarterly. Illustrated \$24.95
Confronting the Color Line The Broken Promise of the Civil Rights Movement in Chicago Alan B. Anderson and George W. Pickering

"A most engrossing treatment of the civil rights movement in Chicago in the mid-r970s. . . . The author's major premise is that politics constitute an inescapably moral enterprise"-Washington Book Review.

"A rewarding, challenging work. ... . It is a model explication of strategy, conflict, and leadership on race issues. After showing the promising Chicago movement's collapse, the book returns to the broader issue of race in American society"-Library Journal.

Illustrated \$40.00 cloth; \$17.95 paper

\section{Federal Law and Southern Order}

\section{Racial Violence and Constitutional Conflict in the Post-Brown South Michal Belknap}

Probing the federal government's failure to respond to the racial violence that raged through the South in the wake of Brown, Michal Belknap shows that only after white southerners themselves suppressed the night riding and terrorism that threatened to plunge their region into anarchy did Washington move to protect black's constitutional rights. Illustrated \$35.00 


\section{New from MIT}

PROSPECTS FOR PEACEMAKING

A Citizen's Guide to Safer Nuclear Strategy edited by Harlan Cleveland and Lincoln P. Bloomfield

Prospects for Peacemaking demystifies the critical issues of war, peace, and national security and clears the way for a security policy based less on outmoded premises and more on nuclear world. It demonstrates one model of a creative interaction between citizens and specialists, one that can be replicated in any community.

a purposeful strategy for peace in a

\section{TOWARD A LIVABLE WORLD}

\section{Leo Szilard and the Crusade for Nuclear Arms Control}

\section{Leo Szilard}

edited by Helen S. Hawkins, G. Allen Greb

Introduction by Barton J. Bernstein and

Gertrud Weiss Szilard

Toward a Livable World documents

Szilard's energetic attempts to influence public policy on arms control and disarmament issues, both through

Washington power sources and a remarkable exercise in personal behind-the-scenes contacts with diplomacy with Nikita Krushchev.

New in Paperback

\section{HOW PEACE CAME TO THE WORLD edited by Earl W. Foell and Richard A. Nenneman}

"How Peace Came to the World is an arresting and evocative compendium of scenarios that imagine a sustainable future for our planet. Almost all of [the essayists] agreed on a central point: that Americans and Soviets must accommodate themselves to each other. They will either coexist or not exist. The book is a superb reminder that people everywhere owe a duty to the children to safeguard the future."

- International Physicians for the Prevention of Nuclear War, winners of the 1985 Nobel Peace Prize

$\$ 7.95$ paper

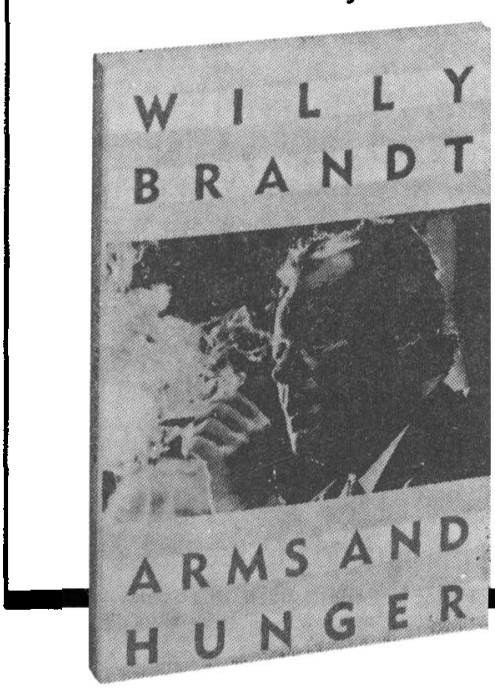

\section{ARMS AND HUNGER Willy Brandt}

In this strongly worded book, Brandt goes beyond the diplomatic role he has formally played and describes the major problems plaguing the globe today, as well as solutions for them. From Brandt's personal observation and personal experience, he demonstrates that the West has failed to meet today's challenges and delivers a frank criticism of the Reagan administration's policies - or lack of them.

"Brandt's findings, like his suggestions, are realistic and discriminating. - The New Yorker $\$ 7.95$ paper 


\section{The best in Political Science}

\section{BETTER A SHIELD THAN A} SWORD

\section{Perspectives on Defense and Technology EDWARD TELLER}

These personal reflections reveal the public and private Edward Teller-one of the most eminent and controversial scientists of the 20th Century-who offers his frank appraisal of the development of the hydrogen bomb and his role in the Oppenheimer controversy, and his influential views on arms control, the Strategic Defense Initiative, and nuclear policy.

1987 ISBN:0-02-932461-0 $\$ 19.95$

\section{GOVERNING PRISONS}

\section{A Comparative Study of Correctional Management \\ JOHN J. DIIULIO, JR.}

Widely believed to be a breeding ground for crime rather than a punishment for it, corrections expert John J. Dilulio argues that the American prison can be governed in ways that encourage civilized behavior, and constitute punishment that is just as well as merciful. "An insightful analysis of the complex problems involved in managing our burgeoning correctional systems." - Norman A. Carlson, Director, Federal Bureau of Prisons

\section{ISBN: 0-02-907881-4 $\$ 24.95$}

\section{THE QUESTION OF PORNOGRAPHY}

Research Findings and Policy

Implications

EDWARD DONNERSTEIN, DANIEL LINZ, and

\section{STEVEN PENROD}

This analysis of the scientific findings to date on the impact of media sex and violence reveals that sexually-explicit material-in itself - does not foster negative behavior unless it is combined with images of violence. Rejecting censorship, the authors recommend realistic strategies to offset the negative effects of all violent sexual images-from prime-time TV to pornography. "Will not be the last word in this constantly evolving controversy, but no thoughtful discussion can ignore its findings." -Alan M. Dershowitz, Harvard University

1987 ISBN: 0-02-907521-1 \$24.95
A CENTENNIAL HISTORY OF THE AMERICAN ADMINISTRATIVE STATE RALPH CLARK CHANDLER, Editor

"Chandler has done the field of public administration a great service by putting together... a who's who of virtually every leading public administration scholar in the country. Should be exciting reading and a significant reference document to all of those who study, practice, or teach public administration."-H. George Frederickson, President, Eastern Washington University

\section{ISBN:0-02-905301-3 \$45.00}

\section{HOLIYWOOD GOES TO WAR}

\section{How Politics, Profits, and Propaganda} Shaped World War II Movies

CLAYTON R. KOPPES and GREGORY D. BLACK "Has the tremendous virtue of being at once highly entertaining, impeccable in scholarship, and provocative in the larger themes it illuminates. It will appeal not only to film buffs and students of World War II, but to everyone concerned with the mass media, with issues of censorship, and with the interaction of popular culture and political ideology."-Paul Boyer, University of Wisconsin-Madison

1987 ISBN: 0-02-903550-3 $\$ 22.50$

\section{KOREA}

The War Before Vietnam

CALLUM A. MACDONALD

"Exhaustively researched, well-written, and intelligent...a real achievement."-William O'Neill, Rutgers University

1987 ISBN:0-02-919621-3 \$24.95

\section{AIR BATTLE CENTRAL EUROPE}
ALFRED PRICE
"A first-rate introduction to tactical air warfare in the European theatre... must reading for any- one interested in understanding NATO air oper- ations."-Allan R. Millett, Ohio State University 1987 ISBN: 0-02-925451-5 \$17.95 


\section{from THE FREE PRESS |F्P|}

\section{TO RAISE AN ARMY}

The Draft Comes to Modern America JOHN WHITECLAY CHAMBERS, II

"The first authoritative account of one of the miracles of recent history-the raising of a great army within a little more than a year. Prodigiously researched, objective and fair, and beautifully written-a notable contribution to American historical literature."-Arthur-S. Link, Editor of The Papers of Woodrow Wilson, Princeton University

1987 ISBN: 0-02-905820-1 $\$ 24.95$

\section{THE FOUR DAYS OF COURAGE}

\section{The Untold Story of the People Who \\ Brought Marcos Down \\ BRYAN JOHNSON}

"Clarifies one of the most myth-ridden events of recent times...May well be the best book on the Ferdinand Marcos-Corazon Aquino election campaign and on the "People Power" that toppled a tyrant, a narrative reminiscent of that Vietnam-era classic, Michael Herr's Dispatches, but without the hallucinations."

- The New York Times Book Review

1987 ISBN:0-02-916571-7 \$19.95

\section{GEORGE WASHINGTON}

\section{The Making of An American Symbol}

BARRY SCHWARTZ

"In this solidly researched yet sparkling book, Mr. Schwartz, venturing into an apparently almost exhausted field, manages to deal freshly, shrewdly, and also affectionately with George Washington as the prime example of American hero-worship."-Marcus Cunliffe, The George Washington University

1987 ISBN:0-02-928141-5 $\$ 22.50$

\section{THE PRIDE AND THE FALL} The Dream and Illusion of Britain as a Great Nation

CORRELLI BARNETT

"Brilliant...chilling...debunking... a formidable book, essential reading."-Financial Times 1987 ISBN: 0-02-901851-X $\$ 22.95$

\section{REMAKING JAPAN}

The American Occupation as New Deal

THEODORE COHEN, Edited by Herb Passin

In this fascinating, behind-the-scenes story, occupation-force insider Theodore Cohen chronicles the six crucial post-war years when a handful of Americans, governed by New Deal tenets, laid the foundation for modern Japantransforming it from a feudalistic society to a nation of middle class consumers.

1987 ISBN: 0-02-906050-8 $\$ 27.50$

\section{SAVING THE REVOLUTION \\ The Federalist Papers and The American Founding}

CHARLES R. KESLER, Editor

In honor of the Constitution's bicentennial, thirteen of America's preeminent scholars -including Edward C. Banfield, Harvey C. Mansfield, Jr., and Jack N. Rakove-offer fresh insights into The Federalist Papers: its ideals, arguments, and enduring effects on American political life.

1987 ISBN: 0-02-919730-9 \$29.95

\section{LIBEL LAW AND THE PRESS Myth and Reality \\ RANDALL P. BEZANSON, GILBERT \\ CRANBERG, and JOHN SOLOSKI}

Based on the pioneering lowa Libel Research Project, three media experts challenge traditional beliefs about the intent and consequences of libel law-and present overwhelming evidence of a faulty libel system that protects no one. Offering practical suggestions that could significantly reduce costly litigation, this study points the way toward profound libel law reform while protecting the rights the law originally sought to secure.

1987 ISBN: 0-02-905870-8 $\$ 40.00$

TO CHARGE BOOKS BY PHONE to your VISA or MasterCard, call toll-free 1-800-257-5755 (In NJ, AK, or Hl, dial direct 1-609-461-6500).

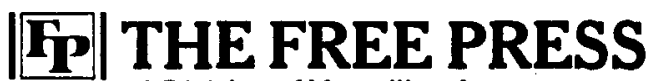
A Division of Macmillan, Inc. 866 THIRD AVENUE, NEW YORK, NY 10022 


\section{A new SETUPS - with a data set for microcomputer users or mainframe computer users . . .}

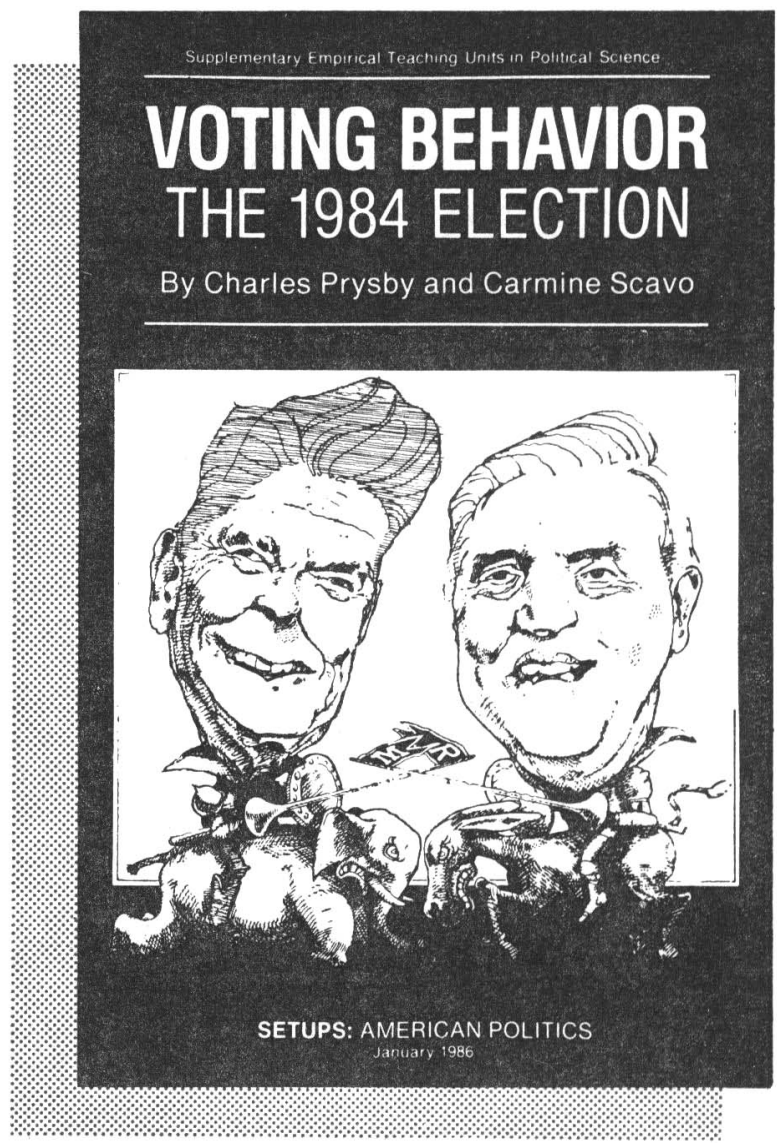

The SETUPS includes a monograph for students and a data set.

\section{The monograph features:}

- a description of the 1984 election

- an introduction to voting behavior and survey research

- a set of data analysis exercises

- a codebook for the data set

- a bibliography

\section{The data set is} available for:

- mainframe computers, on tape. in an SPSSX export file and OSIRIS data and dictionary files

- microcomputers - IBM-PC compatible machines, on diskette, in an $A B C$ data set

The SETUPS monograph is $\$ 6.50 /$ copy, \$5.20/copy on orders of 25 or more. All orders must be prepaid. The data are free with orders of 25 or more monographs. To order write: 


\section{LEXINGTON BOOKS}

THE PUBLISHER OF CHOICE ON POLITICS AND POLICY

NEWTEXT!

American Defense Annual, 1987-1988

Joseph Kruzel, Mershon Center, The Ohio State University, editor

The third volume in the widely acclaimed series sponsored by the Mershon

Center at the Ohio State University. Top defense experts bring a wide range of political views to their stimulating discussions of American security policy.

Collectively, they provide readers with a balanced overall perspective on the issues.

15091-6 1987416 pp. $\$ 45.00$ (cl)

$15090-8 \$ 16.95$ (pb/text)

\section{NEWTEXTI}

\section{Democracy, Strategy, and Vietnam}

Implications for American Policymaking

George K. Osborn, Asa A. Clark, IV, Daniel J. Kaufman, and Douglas E. Lute, all professors at the U.S. Military Academy at West Point, editors

Has American national security policy changed substantially as a result of the Vietnam experience? This book examines that vital question and answers it primarily in the negative.

16340-6 1987400 pp. $\$ 35.00$ (cl)

$16341-4 \$ 16.95$ (pb/text)

\section{NEWTEXT!}

\section{Financing the 1984 Election}

Herbert E. Alexander and Brian A. Haggerty, Citizens' Research Foundation

A detailed look at the role money played in the campaigns of each of the major contenders for presidential nomination in 1984. It also describes Congressional efforts to develop appropriate finance legislation from 1983 to 1986 and discusses the activities of the Federal Election Commission.

14885-7 1987448 pp. $\$ 45.00$ (cl)

$16256-6 \$ 14.95(\mathrm{pb} /$ text $)$

\section{Dealing with Drugs}

Consequences of Govemment Control

Ronald Hamowy, University of Alberta, editor

Experts explore drug policy and control in the U.S. , its numerous failures, and suggest new approaches to managing our illegal drug problems.

"Another step forward in our understanding of drug problems and government's responses to them. This is an incisive book for all those who want to understand the real issues we are facing." - John Kaplan, Professor of Law, Stanford University

$15678-71987400$ pp. $\$ 40.00$ (cl) 


\section{Excellence in Polfirical Science}

Introduction to Politics

Vernon Van Dyke, University of lowa. ISBN 0-8304-1089-9

The Supreme Court in the Federal Judicial System (revised)

Stephen L. Wasby, SUNY, Albany. ISBN 0-8304-1175-5

Politics, Parties, and Elections in America

John F. Bibby, University of WisconsinMilwaukee. ISBN 0-8304-1060-0

\section{Introduction to Social}

Science

Wesley M. Bagby, West Virginia University.ISBN 0-8304-1146-1

Political Theory:

A Thematic Inquiry

James $L$. Wiser,

Loyola University, Chicago.

ISBN 0-8304-1069-4

The American Presidency:

A Policy Perspective from

Readings and

\section{Documents}

David C. Kozak, National War

College, and Kenneth N. Ciboski,

Wichita State University, editors.

ISBN 0-8304-1053-8

\section{$\star \star$ Forthcoming $\star \star$}

Introduction to International Relations

David Farnsworth, Wichita State

University.

ISBN 0-8304-1101-1, Spring 1988
The American Bureaucracy

Richard J. Stillman, II, George Mason

University. ISBN 0-8304-1052-X

Atlantis: Role Playing

Simulations for the Study of American Politics

W. Robert Gump and James R.

Woodworth, Miami University.

ISBN 0-8304-1137-2 spiral, Instructor's

Resource Manual

Policy Analysis in

Political Science

Randall B. Ripley,

The Ohio State University.

ISBN 0-8304-1058-9

Ethics and Politics:

Cases and Comments

Amy Gutmann, Princeton University, and Dennis F. Thompson, Harvard University, editors.

ISBN 0-8304-1115-I

Introduction to

Comparative Politics:

Comparing Political

System Performance in

Three Worlds

John D. Nagle, Syracuse University.

ISBN 0-8304-1042-2

\section{Law and Justice}

Howard Abadinsky, St. Xavier

College, Chicago.

ISBN 0-8304-1188-7

To request exam copies, please stote course title, present text, and enrollment on your letterhead and send it to Nelson-Hall College Division.

\section{Melson-Hall Publishers}

111 N. Canal, Chicago 60606

Series Consulting Editor: Samuel C. Patterson, The Ohio State University 


\section{China Watch John King Fairbank}

America's top China-watcher here presents his most extensive writings on post-revolutionary China, providing an unrivaled overview of that nation and of Chinese-American relations.

\section{Political Ethics and Public Office}

\section{Dennis F. Thompson}

Thompson surveys ethical conflicts of public officials over a spectrum of political issues, developing a conception of political ethics that respects the demands of both morality and politics.

\section{From Deterrence to Defense}

The Inside Story of Strategic Policy

\section{Michael Chartton}

Candid interviews with the architects of

American nuclear policy.

"Excellent ... Charlton's line of questioning could hardly have been bettered."

\section{- Times Literary Supplement} $\$ 20.00$ cloth, $\$ 8.95$ paper

\section{Whose Votes Count? \\ Affirmative Action and Minority Voting Rights \\ Abigail M. Themstrom}

"This book is a perfect event. ... It is necessarily the 'standard work' for anyone seriously interested in the politics, law, and modern history of the Voting Rights Act."

-William Van Alstyne,

Duke University School of Law

A Twentieth Century Fund Study

$\$ 25.00$

\section{The Chinese Army After Mao \\ Ellis Joffe}

"An excellent study ... [ Joffe] is superbly equipped to provide a sophisticated understanding of a highly elusive matter: China's military modernization and the politics of civil-military relations."

-Allen S. Whiting, University of Arizona

$\$ 20.00$

\section{Another Liberalism Romanticism and the Reconstruction of Liberal Thought Nancy L. Rosenblum}

"A highly original work - beautifully written, brimming with insights, and a real pleasure to read ... A major contribution to the debate about the nature and origins of liberalism."

-Stephen Holmes, University of Chicago

$\$ 25.00$

\section{Liberalism and American Constitutional Law Rogers M. Smith}

"This is a very challenging and important book. Impressive in scholarship and ambitious in scope, Smith's volume represents a sophisticated attempt to develop from our limited tradition a purposive theory for reorienting contemporary constitutional debates." - American Political Science Review

$\$ 22.50$

available in paperback

\section{Fighting Poverty}

What Works and What Doesn't Edited by Sheldon H. Danziger and Daniel $H$. Weinberg

"For those who want an informed, balanced, and realistic, but not despairing, consideration of anti-poverty policy, this is the book." Perspective

$\$ 10.95$ paper 


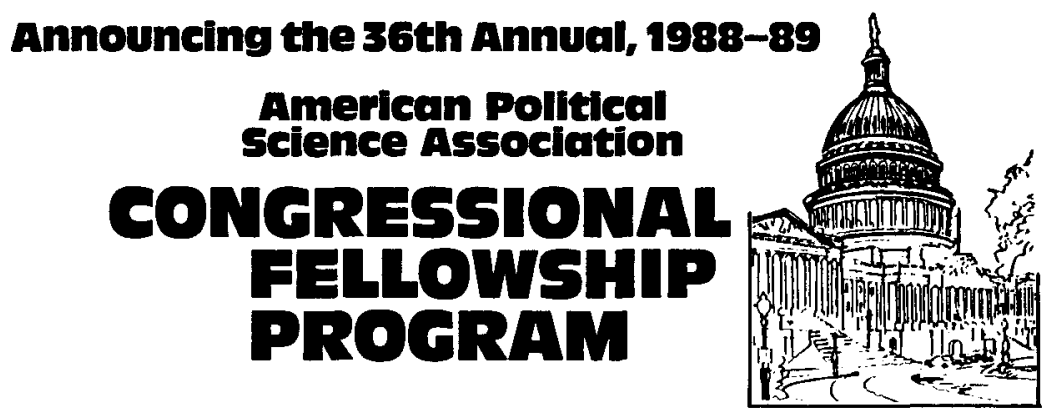

\section{Political Scientists}

Opportunities for young and mid-career political scientists to learn more about the legislative process by working as congressional aides for nine months.

Qualifications: Scholarly interest in Congress and the policy process and a Ph.D. completed within the last fifteen years (or near completion). Stipend: $\$ 20,000$, plus travel allowance. The fellowship stipend may be supplemented, at the fellow's initiative, with university support.

Fellowship Year: Orientation begins in November 1988; office assignments run from December 1988 through August 15, 1989.

Applications: Application materials must be submitted prior to December 1, 1987. Awards will be announced by March 16, 1988.

\section{Application Procedures}

For Pollifical Sclentists who have completed their Ph.D. within the last fifteen years or are near completion, submit six copies of:

-A detailed curriculum vitae;

-A personal statement of about 500 words explaining how the Congressional Fellowship Program relates to your professional career goals;

-A sample of your best professional writing (one published or unpublished manuscript or paper.)

In addition, applicants should submit the names of three professional references who will send letters of recommendation to our office by December 15, 1987, (You are responsible for seeing that these letters are sent.)

By December 1, 1987 send to: Director

Congressional Fellowship Program American Political Science Association

1527 New Hampshire Avenue, N.W. Washington, D.C. 20036

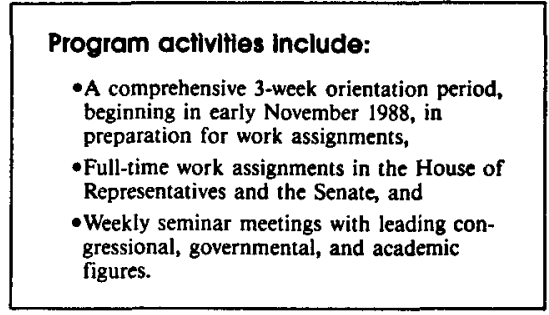

\section{Chairman of the \\ Congressional Fellowship \\ Program Advlsory Committee}

Nelson W. Polsby, University of California, Berkeley

Former Congressional Fellows Include:

Chartes Bullock, University of Georgis

Richard Cheney, Chairman, U.S. House Republican Conference

Lawreace Dodd, Indiana University

Murray P. Dry, Middlebury College

Delmer Duna, University of Georgis

Ada W. Finifter, Michigan State University

Alton Frye, Council on Foreign Relations

Robert Healy, Atlantic Richfield Company

Chartes Henry, University of California, Berkeley

George Kundanis, Office of Rep. Thomas S. Foley

Eve Lubalin, Office of Senator Frank R. Lautenbers

David B. Magleby, Brigham Young University

Thomas E. Mann, The Brookings Inssitution

John Mankey, Stanford University

David Maybew, Yale University

Bruce Oppeabeimer, University of Houston

Bruce Oppeabeimer. University of Houston

Bruce W. Robeck, Texas AaM University

David Rohde, Michigan State University

Alan Rosenthal, Rutgers University

Mark A. Siegel, Mark A. Siegel and Associates

Barbara Sinclair, University of California, Riverside

Terry Sulliven, University of Texas, Austin

Howard Swearer, President, Brown University

Marcia L. Whicker, University of South Caroling

Raymond Wolfinger, University of California, Berkeley

Chartes E. Young, Chancellor, UCLA 


\section{New in the \\ Pitt Series in \\ Policy and Institutional Studies}

\section{PESTICIDES AND POLITICS: \\ The Life Cycle of a Public Issue \\ Christopher J. Bosso}

Traces the long battle over the control of pesticides through forty years of technological and political change. $1987 / 312$ pages/\$29.95

\section{AGENCY MERGER AND BUREAUCRATIC REDESIGN}

Karen M. Hult

Explores the aftermath of merger in three community development agencies, providing significant insights into why mergers do or do not succeed. $\quad 1987 / 235$ pages $/ \$ 28.95$

\section{POLICY ANALYSIS BY DESIGN}

Davis B. Bobrow and John S. Dryzek

Examines the analytical approaches to public policy taken by those who teach it, write about, and influence it through analysis.

November 1987/Approx. 240 pages/\$27.95 cloth, \$13.95 paper

\section{CONGRESS AND ECONOMIC POLICYMAKING}

Darrell M. West

An illuminating new study of congressional decision making on economic policy during the Reagan administration.

December 1987/Approx. 176 pages/\$22.95 cloth, \$9.95 paper (tentative prices)

Also of Interest

\section{AUTHORITARIANS AND DEMOCRATS:}

Regime Transition in Latin America

James M. Malloy and Mitchell A. Seligson, Editors

A collection of case studies by leading Latin American scholars addressing the recent revival of democracy in Latin America. $1987 / 278$ pages/\$25.95 cloth, \$12.95 paper

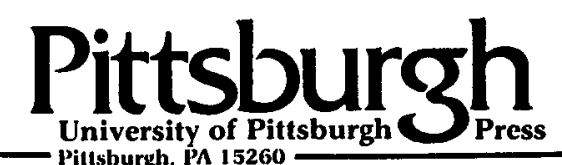


PRESS

\section{CQ Press ... the frontrunner in political science in $\mathbf{1 9 8 8}$}

\section{JUST PUBLISHED}

The Politics of the Presidency

Second Edition

Richard A. Watson, University of Missouri-Columbia

Norman C. Thomas, University of Cincinnati

547 pages. $\$ 17.95$.

The Presidency and the Political System

Second Edition

Michael Nelson, editor, Vanderbilt University

498 pages. $\$ 17.95$.

Parties, Politics, and Public Policy in America Fifth Edition

William J. Keefe, University of Pittsburgh

300 pages. $\$ 14.95$.

Government by Proxy

(Mis?)Managing Federal Programs

Donald F. Kettl, University of Virginia

170 pages. $\$ 10.95$.

Polling and the Public

What Every Citizen Should Know

Herbert B. Asher, Ohio State University

168 pages. \$11.95.

State Government

CQ's Guide to Current Issues and Activities 1987-88

Thad L. Beyle, University of North Carolina-Chapel Hill

editor

App. 220 pages. $\$ 9.95$.

CQ's Guide to Current American Government Fall 1987

App. 165 pages. $\$ 9.95$. 


\section{NEW FOR 1988}

The Presidential Contest

Third Edition

Richard A. Watson, University of Missouri-Columbia

Available for examination and adoption October 1987

The Elusive Executive

Discovering Statistical Patterns in the Presidency

Gary King, Harvard University

Lyn Ragsdale, University of Arizona

Available for examination and adoption December 1987

American Foreign Policy Since World War II Eleventh Edition

John Spanier, University of Florida

Available for examination and adoption January 2, 1988

\section{NEW FOR 1987}

\section{Governing}

Readings and Cases in American Politics

Roger H. Davidson and Walter J. Oleszek, editors

Congressional Research Service

Games Nations Play

Sixth Edition

John Spanier, University of Florida

Change and Continuity in the 1984 Elections

Revised Edition

Paul R. Abramson, Michigan State University

John H. Aldrich, Duke University

David W. Rohde, Michigan State University

Energy, Politics, and Public Policy

Second Edition

Walter A. Rosenbaum, University of Florida

Basic Cases in Constitutional Law

Second Edition

Duane Lockard (emeritus) and Walter F. Murphy, editors

Princeton University

The Politics of Shared Power

Second Edition

Louis Fisher, Congressional Research Service

CQ Press $\bullet$ College Services $\bullet 1414$ 22nd Street, NW $\bullet$ Washington, DC 20037 


\section{New York University Press}

\section{The Making of Modern Society \\ ROBERT NISBET}

"An excellent book and a valuable source of reference. The autobiographical information is particularly fascinating."

-Tom Bottomore, author of A Dictionary of Marxist Thought 224 pages ISBN 0-8147-5761-8 $\$ 40.00$

\section{Conflict Management and Problem Solving} Interpersonal to International Applications

DENNIS J. D. SANDOLE and INGRID SANDOLE-STAROSTE, Editors Includes state-of-the-art theory, research, and practice of conflict management in family, community, and labor relations and also deals with hostagetaking situations and with international relations.

320 pages $I S B N 0-8147-7866-6 \quad \$ 40.00$

\section{Centre Formation, Protest Movements, and Class Structure in Europe and the United States \\ SHMUEL NOAH EISENSTADT, L. RONIGER, and A. SELIGMAN}

This collection of original studies analyzes various aspects of the configuration of modern Western European nation-states and the United States.

220 pages ISBN 0-8147-2171-0 $\$ 30.00$

\section{Manhattan Water-Bound}

Planning and Developing Manhattan's Waterfront from the

Seventeenth Century to the Present

ANN L. BUTTENWIESER

"Ann Buttenwieser... has deftly traced three centuries of history.... Manhattan Water-Bound describes the glory of the port's past, and offers a look into its future." - Henry J. Stern, Commissioner, New York City Department of Parks and Recreation

192 pages ISBN 0-8147-1093-X $\$ 30.00$

NEW YORK UNIVERSITY PRESS

WASHINGTON SQUARE • NEW YORK, N.Y. 10003 
New from Wisconsin

SOVIET-EAST

EUROPEAN RELATIONS

Consolidation and

Conflict, 1968-1980

Robert Hutchings

\$12.50 Paper

SECTIONALISM AND

AMERICAN POLITICAL

DEVELOPMENT, 1880-1980

Richard Franklin Bensel

$\$ 14.95$ Paper

DEMOCRACY AND

PUNISHMENT

Disciplinary Origins of

the United States

Thomas L. Dumm

$\$ 40.00$ Cloth $/ \$ 15.75$ Paper

THE FRANCO REGIME

1936-1975

Stanley G. Payne

$\$ 30.00$ Cloth

THE ORIGINS OF MODERNITY

The Origins of Modern Social

Theory from Kant to Marx

John Rundell

$\$ 36.00$ Cloth

THE POST-INDUSTRIAL

UTOPIANS

Boris Frankel

$\$ 35.00$ Cloth $/ \$ 12.50$ Paper

THE ORGANIZATIONAL STATE

Social Change in National

Party Domains

Edward O. Laumann

and David Knoke

$\$ 45.00$ Cloth $/ \$ 19.95$ Paper

POLITICAL EDUCATION IN

THE SOUTHERN FARMERS

ALLIANCE, 1887-1900

Theodore Mitchell

$\$ 39.50$ Cloth $/ \$ 16.50$ Paper

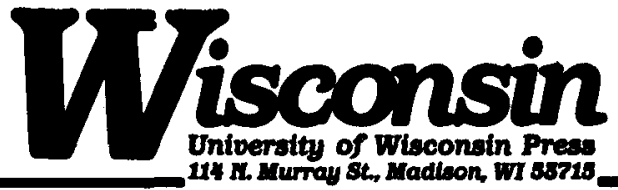




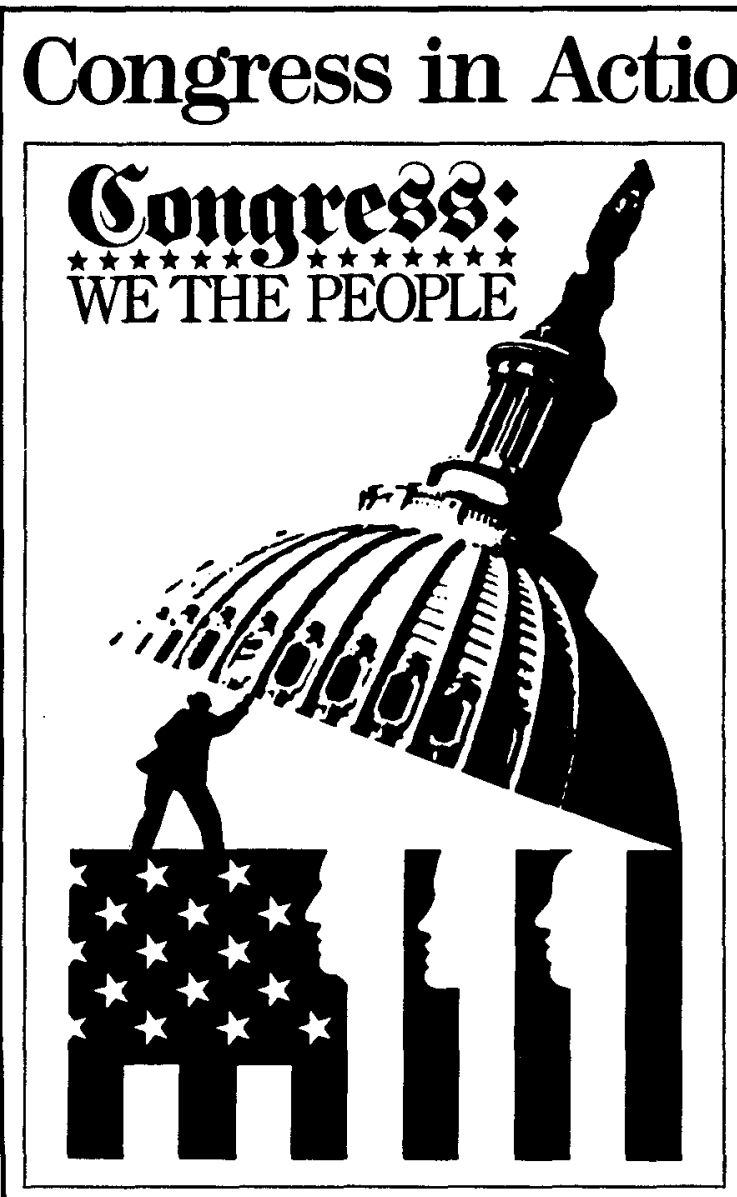

For more information about how you might use Congress: We The People call 1-800-LEARNER. For review copies of the Study Guide and Faculty Guide which have been designed to accompany the series call the American Political Science Association, 1-202-483-2512.

Educational Excollenke Through Telexommunications

\section{An Annenberg/CPB Project}

Congress: We The People is an exciting new resource for political science courses on Congress and the legislative process.

The series includes 26 half-hour video cassettes that show the dayto-day activities of Congress and provide analysis and commentary by leading political scientists.

Faculty are finding that Congress: We The People is an excellent supplement to existing courses. Among the topics addressed are: congressional elections; committee leadership; lobbying; constituent relations; lawmaking; budgeting; ethics; and congressional relations with the President, courts and the media.

The series is also being used as a complete broadcast telecourse for students who complete most of their study off-campus, and as a resource for noncredit and informal study.

Congress: We The People is hosted by Norman Ornstein, Catholic University, and Edwin Newman, noted journalist. It was produced by the American Political Science Association and WETA, the public television station in Washington, D.C. A special feature of Congress: We The People is its adaptation for use with any of following three commonly used textbooks:

- Congress and Its Members by Roger $H$. Davidson and Walter $J$. Oleszek, Congressional Quarterty Press, Washington, D.C. 1985.

- The United States Congress: People, Places and Policy by Charles $\mathrm{O}$. Jones, the Dorsey Press, Homewood, Illinois, 1982. - Congress: Process and Policy by Randall B. Ripley, W.W. Nonton and Company, New York, 1983. 


\section{Chronicles of American power and powerlessness-past, present, and future}

\section{THE CLASSIC SLAVE NARRATIVES}

Edited by Henry Louis Gates, Jr., Ph.D. These autobiographical narratives offer insight into the slaves' struggle for recognition às human beings entitled to dignity and freedom. In addition to the works of Frederick Douglass and Olaudah Equiano, this original anthology includes the writings of Mary Prince and Harriet Jacobs (a.k.a. Linda Brent), never before available in paperback. (i) MENTOR 0-451-62564-1 \$4.95/\$5.95*

\section{LAY BARE THE HEART \\ An Autobiography of the \\ Givil Rights Movement}

By James Farmer. The founding director of CORE eloquently recounts the excitement and turmoil of the civil rights movement of the 1950 s and $60 \mathrm{~s}$. Unsparing of himself and forthright about others-Martin Luther King, Jr., John F. Kennedy, Malcolm XFarmer has created "an invaluable contribution to the history and literature of the unfinished civil rights movement." - Julian Bond, in Atlanta Magazine

(D) PLUME 0-452-25803-0 \$8.95/\$11.95*

\section{THE TWILIGHT OF THE PRESIDENCY}

From Johnson to Reagan

Revised Edition

By George E. Reedy. Hailed by The New York Times as "one of the most thoughtful, stimulating, and alarming essays on American government," when it was first published, this landmark book has now been completely revised to provide fresh insight and analysis into the current structure of the Presidency. From Johnson to Reagan, Reedy describes the virtually unchecked power that works to corrupt the office of the President. A new afterword addresses the Iran-Contra scandal and its probable effect on future Presidents.

궁 NAL BOOKS $0-453-00567-5 \$ 17.95 / \$ 24.95 *$

\section{THE REAGAN \\ FOREIGN POLICY}

\section{A Foreign Affairs Reader}

Edited and with an Introduction by William G. Hyland. From the pages of Foreign Affairs comes this sharp look at the promises, accomplishments, and disappointments of the first six years of Reagan's administration. Such authors as George Shultz, Richard Nixon, Senator John Tower, James Schlesinger, and Caspar Weinberger discuss South Africa, Star Wars, Central America, the Middle East, human rights, and other controversial issues. Published for the Council on Foreign Affairs.

(3) MERIDIAN 0-452-00889-1 \$9.95/\$13.95*

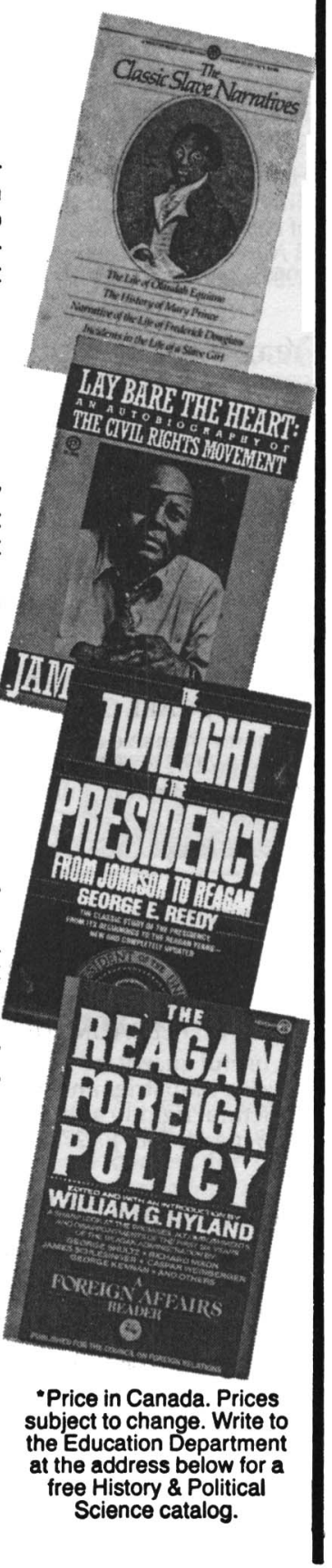




\section{Politics and Vision}

The ADA and American Liberalism, 1947-1985

STEVEN M. GILLON, Yale University

Here, Steven Gillon traces the history of the Americans for Democratic Action (ADA) from its inception as one of the most forceful advocates of liberal ideals following World War II to its redefinition during the Vietnam era, concluding with an analysis of the ADA's influence in liberal

politics today.

1987306 pp. $\$ 24.95$

\section{Democracy, Liberty, and Equality}

ROBERT A. DAHL, Yale University

Here, esteemed political scientist Robert A. Dahl reflects on the continuing confrontation of three different theoretical visions-capitalism, socialism, and democracy-and assesses the relative merits of each system.

A Nortwegian University Press Publication

1987286 pp. $\$ 32.50$

\section{Yearbook of World Armaments and Disarmament 1987}

\section{STOCKHOLM INTERNATIONAL PEACE RESEARCH INSTITUTE (SIPRI)}

On the 1986 Yenrbook: "Consistent with SIPRI's high standards, the book is an authoritative source of data.... With its new publisher, it is noticeably more handsome and accessible than in past years." Bulletin of Atomic Scientists. This collection of timely data on world armaments-nuclear and space weapons, chemical and biological warfare, military expenditure, and the arms trade-also covers issues such as the Chernobyl accident, South Africa, and test ban treaties.

(SIPRI)

1987450 pp.; figs, and tables $\$ 55.00$

\section{The Uncertain Course}

New Weapons, Strategies and Mind-Sets

Edited by CARL G. JACOBSEN, Stockholm International Peace Research Institute

A comprehensive analysis of the strategic, military, and technological forces changing the nature and likelihood of war, this book confronts the dangers that exist in a world with 21st-century weapons and a 19 th-century mind-set.

(SIPRI)

1987374 pp. $\$ 54.00$

Now available in paperback

\section{The Decline of the British Economy}

An Institutional Perspective

BERNARD ELBAUM, Unizersity of California, and WILLIAM LAZONICK, Barnard College

"A useful quarry for students of 20th-century industrial and economic history" - Albion. Focusing on specific industries and issues, Elbaum examines the decline of the British economy in terms of its structural rigidity and historic changes in the world economy.

1986 (paper 1987) $272 \mathrm{pp}$. cloth $\$ 49.95$ paper $\$ 17.95$

\section{The Politics of Neocorporatism in France}

Farmers, the State, and Agricultural Policy-making in the Fifth Republic

JOHN T.S. KEELER, University of Washington

"Keeler's study is an invaluable and indispensable contribution to our understanding of the complex relationship between the state and society in France's Fifth Republic." - Stanley Hofmann, Harvard University. Keeler's study of the politics of neocorporatism in France introduces an original, sector-oriented theoretical framework suitable for analyzing the corporatization process in any democratic polity.

1987384 pp.; 32 illus. $\$ 39.95$

Prices and publication dates are subject to change.

To order, send check or money order to:

Humanities and Social Sciences Marketing Department

\section{Oxford University Press}




\section{PENN STATE PRESS}

Involvement by Invitation American Strategies of Containment in Iran

\section{Kuross A. Samii}

Based on extensive archival research, this book is a perceptive analysis of the historical events that led to America's untidy encounter with the Iranian revolution. Engaging and forthright, it examines AmericanIranian relations against the backdrop of AmericanSoviet rivalry.

"Involvement by Invitation tells the story of America's tangled relation with Iran with great authority, meticulous research and literary grace. Reading Kuross A. Samii's remarkable book one understands what came to pass between the U.S. and Iran: the attraction, the entanglement, and then the feud. A book that merits praise and attention." - Fouad Ajami 208 pages 10 illus. $\$ 24.95$

\section{The Coal of El Cerrejón}

Dependent Bargaining and Colombian Policy Making

Harvey F. Kline

This study of two contracts the Colombian government made for coal development in the early $1980 \mathrm{~s}$ goes beyond the literature on dependencia and on bargaining to closely examine the power struggles between "Nationalists" and "Reactionaries" in the decision-making process. A fascinating study of contract-bargaining and its political, economic, and social effects.

\section{4 pages $\$ 23.50$}

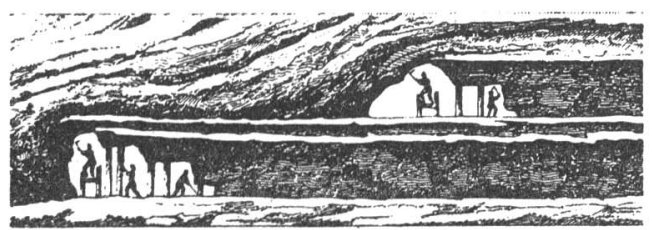

\section{The Origins of Nonviolence \\ Tolstoy and Gandhi in Their Historical Settings \\ Martin Green}

The lives of Tolstoy and Gandhi began at widely separate points - of time, place, social origin, and conviction. In the course of their lives they became, respectively, military officer and novelist, and lawyer and political organizer, but in the last two decades of their lives, they occupied the same special space that of ascetic/saint/prophet. At first agents of modern reform, both men rebelled against it and led a profound resistance.

264 pages $\$ 27.50$

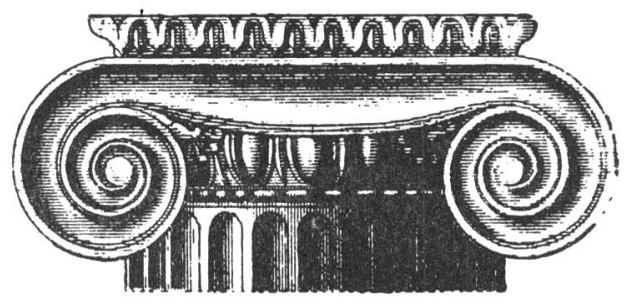

The Athenian Republic Democracy or the Rule of Law? Raphael Sealey

Renowned author Sealey discovers continuity in the constitutional history of ancient Athens, where previous scholars have stressed change. This examination of the legal and social conditions of the inhabitants of Attica, of the sources of Athenian law, and of the sanction of the law - that is, the courts and procedures for administering justice - concludes positively that the Athenians evolved a concept of the rule of law and sought to achieve it by codification and by a system of courts independent of the organs which made policy.

$$
192 \text { pages } \$ 22.50
$$

\section{Coming Soon}

\section{Federal Social Policy The Historical Dimension Donald T. Critchlow and Ellis Hawley, Editors}

A penetrating examination of the development of social policy in 20th-century America, seven original essays explore the historical context for understanding the formulation, implementation, and administration of social policy as it has emerged. Specific essays focus on social policy and women and the aged, social security in the New Deal, and interest group lobbying and the politics of policymaking; others address the broad meaning of the state and the American policy of the 19 th and 20 th centuries.

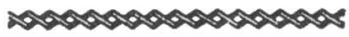

\section{PENN STATE PRESS}

215 Wagner Building

University Park, PA 16802

(814) 865-1327 


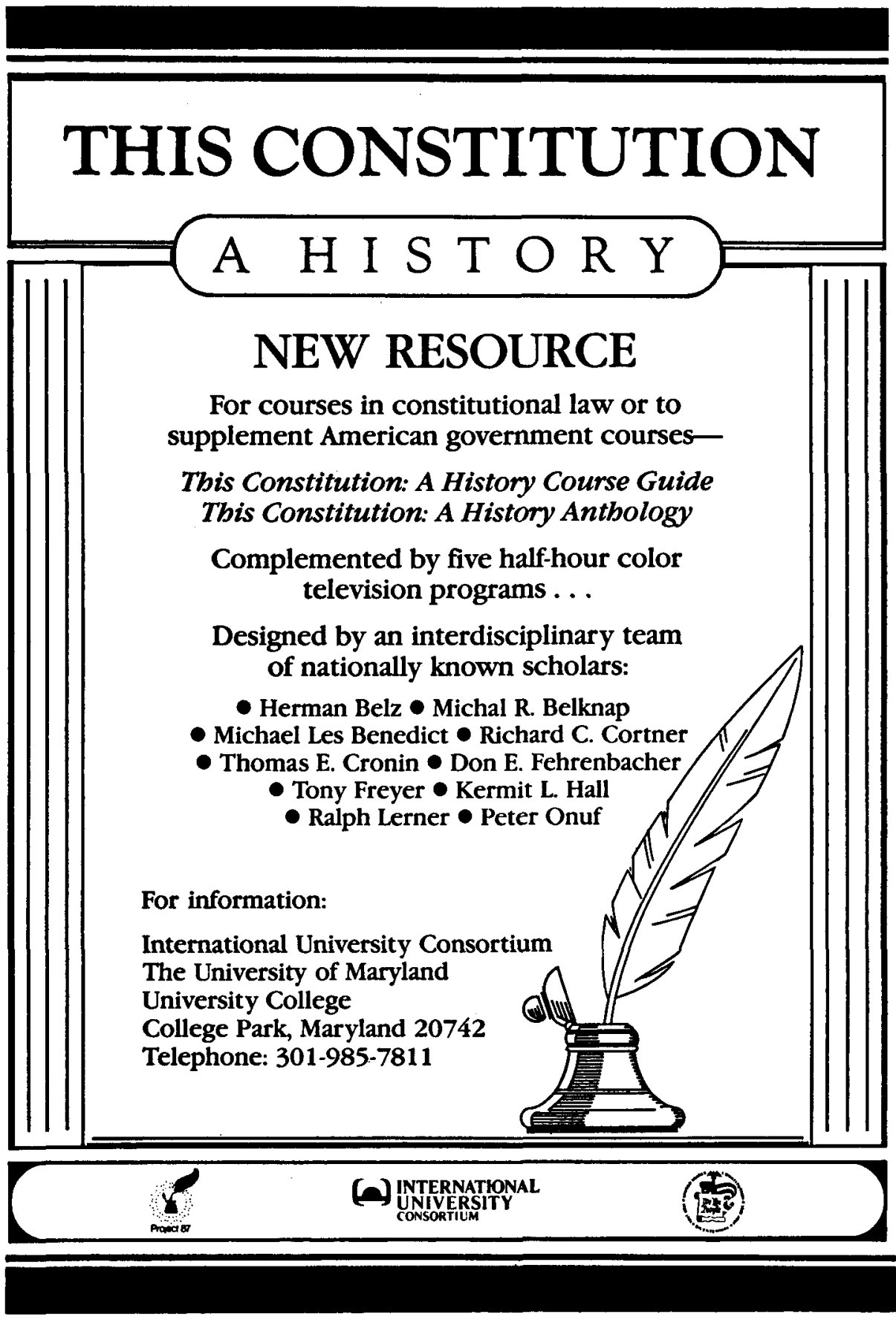




\section{POLITICS Left (1)}

THE LIFE OF THE PARTY

Democratic Prospects in 1988 and Beyond

Robert Kuttner. Part reportage, part manifesto, this timely examination of Democrats past and present traces the party's history from its heyday as the voice of the people to the infighting and lack of focus that characterize its present state. Calling for a return to the traditional Democratic platform, Kuttner outlines a progressive agenda for the 1988 presidential election and for the next decade. Elisabeth Sifton Books. 0-670-81564-0 $256 \mathrm{pp} . \quad \$ 18.95$ hardcover

\begin{abstract}
A FAREWELL TO MARX
An Outline and Appraisal of His Theories

David Conway. This thought-provoking study examines the conflict between Marx's rationally derived, even brilliant, philosophical, political, and economic theories and the less-than-sound presuppositions about society and the world on which they are based. Stripping away layers of preconceived devotion to Marx, this critical reappraisal reveals the most challenging of philosophical thinkers as a man unable to free himself from optimistic illusion.
\end{abstract}

0-14-022365-7 $224 \mathrm{pp}$. \$6.95 paperback

\section{THE FEDERALIST PAPERS}

James Madison, Alexander Hamilton, and John Jay. Edited and introduced by Isaac Kramnick (Cornell University). Considered by Thomas Jefferson to be "the best commentary on the principle of government ever written," the Federalist papers-fully collected here in the first edition texts-represent the definitive exposition of the American Constitution. Isaac Kramnick's introduction traces the genesis and growth of the Federalist papers and the controversy they spurred over two centuries of varying interpretations.

0-14-044495-5 $528 \mathrm{pp}$. $\$ 7.95$ paperback

\section{THE BURGER YEARS}

Rights and Wrongs in the Supreme Court 1969-1986 Edited and introduced by Herman Schwartz. Fifteen essays by expert observers of the Burger Court and leading public affairs activists make up this comprehensive study of the wide-ranging effects and influence of the Court's rulings on such areas as freedom of the press, civil rights, criminal justice, and national security. "Anyone interested in this crucial era will learn much from the kaleidoscope composed by these distinguished authors"-Laurence Tribe, Harvard Law School. Elisabeth Sifton Books.

$0-670-81270-6 \quad 320 \mathrm{pp}$. \$22.95 hardcover

\section{Right AMEPICAN LAKE}

Nuclear Peril in the Pacific

Peter Hayes, Lyuba Zarsky, and Walden Bello. Drawing from previously classified Pentagon files, three journalists reveal the precarious - and reversible-state of the American and Soviet nuclear stand-off in the Pacific, dramatically bringing to light a situation on the brink of a third World War.
0-14-009396-6
$576 \mathrm{pp}$.
$\$ 6.95$
paperback

\section{THE GREENING OF AFRICA}

Breaking Through in the Battle for Land and Food Paul Harrison. A positive response to an environmental crisis plagued with pessimism, this timely survey of Africa's mounting ecological challenges by the author of Inside the Third World provides authoritative background on the continent's struggles with population growth, poverty, and agricultural stagnation and offers workable-and necessary-solutions. 0-14-010192-6 384 pp. $\$ 6.95$ paperback

\section{GEORCE C. MARSHALL. Statesman 1945-1959}

Forrest C. Pogue. Foreword by Drew Middleton. This fourth and final volume of the definitive, authorized biography of one of America's greatest military and civil leaders is "a perfect match between subject and author.... The great biography not just of the year, but of the decade"-Stephen E. Ambrose, University of New Orleans. Illustrated. Also available: Volumes I-III 0-670-81042-8 640 pp. $\$ 29.95$ hardcover

FIGHTINE FAITHS
The Abrams Case, the Supreme Court,
and Free Speech

Richard Polenberg (Cornell University). This superb history vividly recounts the imprisonment and subsequent deportation of four immigrant anarchists whose conviction touched off landmark legal and political debates about the repression of civil liberties. "Definitive...marked by a thoroughness of research, clarity of expression, and soundness of judgement" - Paul Avrich, Queens College. November 1987. $0-670-81373-7 \quad 480 \mathrm{pp}$. $\$ 24.95$ hardcover THE END OF THE THIRD WORLD Newly Industrialized Countries and the Decline of an Ideology Nigel Harris (University College London). Tracing the rapid transformation of Malaysia, Singapore, Indonesia, and Brazil from peasant societies to advanced economies, this insightful study calls for a reassessment of cliche'-ridden and immutable Western ideologies which underestimate the challenge posed by those more adaptable Third World countries.
0-14-022563-3 $240 \mathrm{pp}$. $\$ 6.95$ paperback 


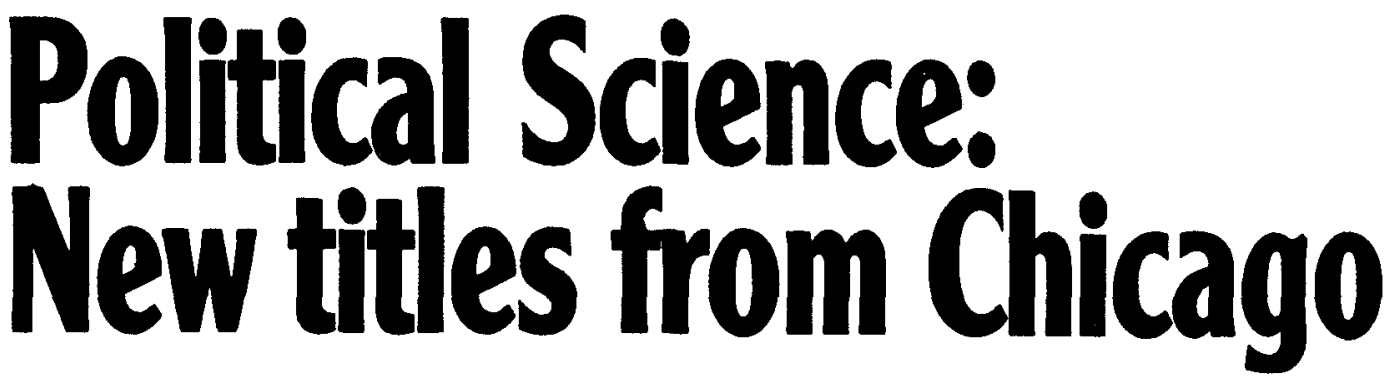

\section{THE FOUNDERS' CONSTIIUTON}

\section{in Five Volumes}

Edited by Phillp B. Krirland and Ralph Lemer

"A singularly valuable offering in this bicentennial year." - Paul A. Freund, New York Times Book Review

Coth, 5 volwanes 3,260 pages $\mathbf{5 3 0 0 . 0 0}$

\section{THE FOUNDERS' CONSTIIUTON}

\section{Major Themes}

Edited by Phitip B. Kurland and Ralph Lemer

Originally published as volume 1 of The Founders' Constitution (a five-volume set)

Paper $\$ 24.95728$ pages

Lbrary doth edtuon \$49.95

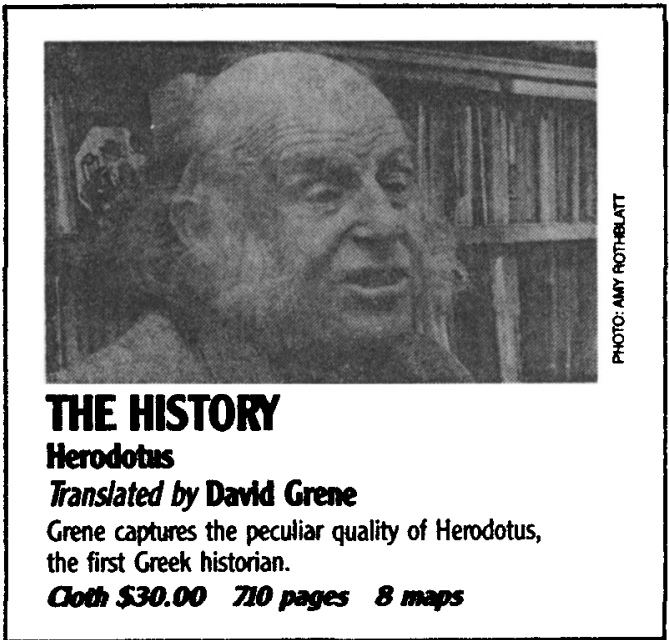

OTY AND REGIME

\section{IN THE AMERCAN REPUBUC}

\section{Stephen L Elin}

This well-written [book] offers an impressive examination of the American city, and breaks important new ground by embedding that examination in a discussion of the American Founding and the ethics of citizenship and participation." - J. David Greenstone, University of Chicago

"A landmark book. Elkin transforms the study of uban politics."

- Edwin T. Haefele, University of Pennsylvania

Paper \$11.95 232 pages

Utrany doth edtion $\$ 35.00$
In paper

\section{THE NEW SCEENCE OF POIITCS}

\section{An Introduction}

With a new Foreword by Dante Germino

Eric Wegelin

$\$ 9.95207$ pages

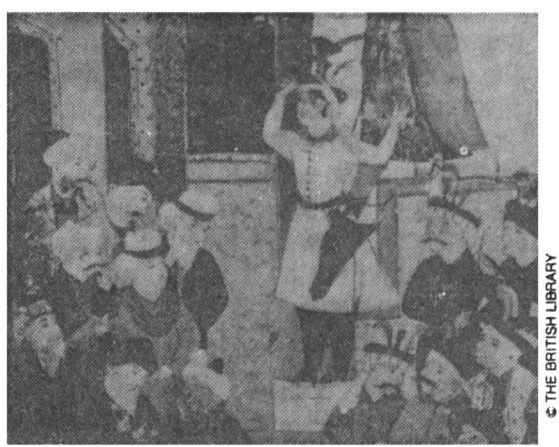

\section{THE SHADOW OF GOD}

\section{AND THE HIDDEN IMAM}

Religion, Political Order, and Societal Change

in Shl'ite Iran from the Beginning to $\mathbf{1 8 9 0}$

Said Amir Arjomand

$\$ 14.95368$ pages 1 haltione

Publications of the Center for Middle Eastem Studies \#D

CONSTRUCTING SOCALL THEORIES

Arthur L Stinchicombe

$\$ 14.95320$ pages

\section{PARTICPATON AND} POLTICAL EQUAUTY

A Seven-Nation Comparison

Sidney Verba, Noman K. Nie, and bae-on Kim

$\$ 55.9546$ pages

PARTICIPATION IN AMERICA

Political Democracy and Social Equality

Sidney Verba and Norman H. Nle

$\$ 15.95456$ pages 


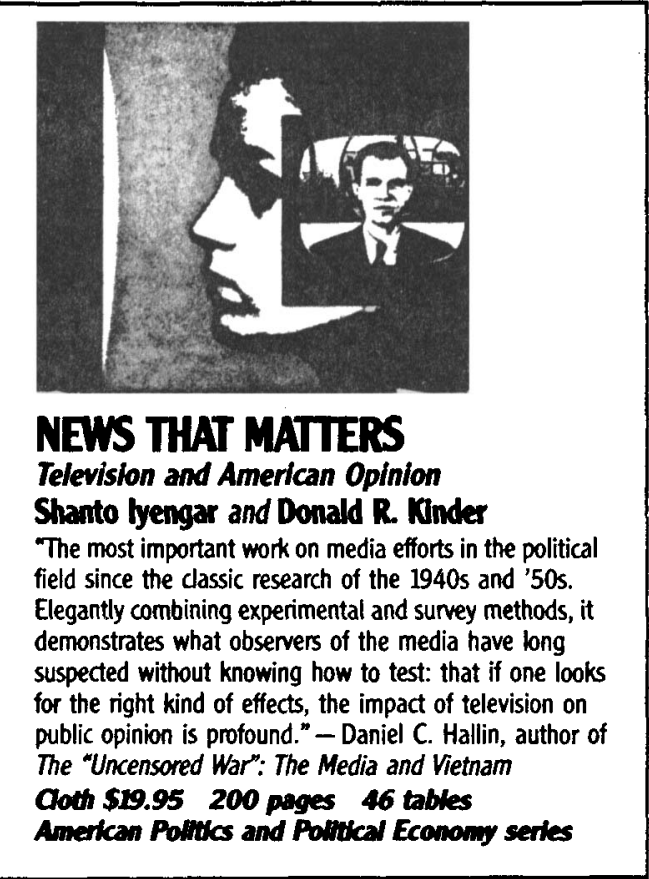

\section{HISTORY OF POUTICAL PHILOSOPHY}

\section{Thind Edition}

Edited by Leo Strauss and Joseph Cropsey

The first new edition in fifteen years.

Paper $\$ 19.95992$ pages

Utbrary doth edition $\$ 75.00$

\section{BEYOND MONOPOY}

\section{Lawyers, State Crises, and \\ Professional Empowerment}

Terence C. Hallday

A pathbreaking study of the legal profession.

Coth $\$ 29.95440$ pages

\section{THE PUBUC DEFENDER}

The Practice of Law in the Shadows of Repute Lisa J. Mdintyre

"Mclntyre challenges conventional wisdom and substitutes compelling new perspectives on the role of the institutional defender." - Milton Heumann, author of Plea Bargaining

Coth $\$ 24.95208$ pages 13 the drawings

\section{THE STATE AND THE CTY}

\section{Ted Robert Curr and Desmond S. King}

A masterful examination of how policies at the local and national state level have a major impad on urban well-being.

Paper $\$ 14.95272$ pages 5 the drawings, 14 tables Whrary doth edition $\$ 35.00$
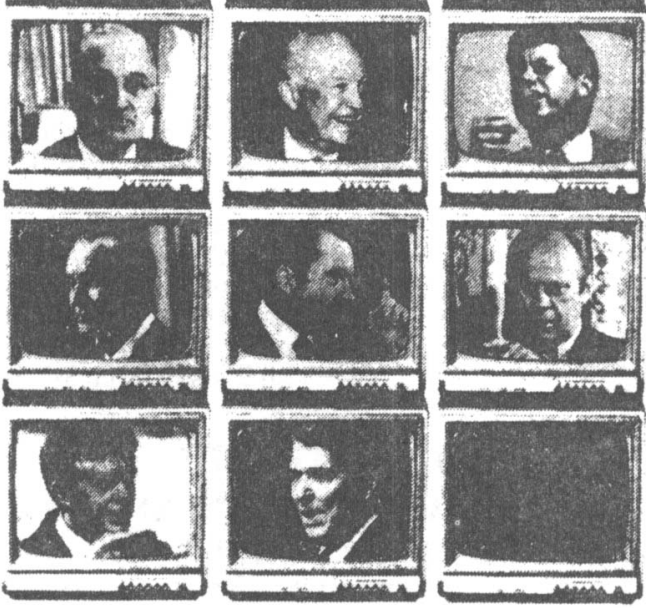

\section{THE SOUND OF LEADERSHIP}

\section{Presidential Leadership in the Modern Age} Roderick P. Hart

"An arresting analysis of the uses, and misuses, of presidential speech." - Daniel Schorr, Senior News Analyst, National Public Radio

Paper \$14.95 296 pages 42 line drawings, 51 tables Lhray cloth edition $\$ 39.95$

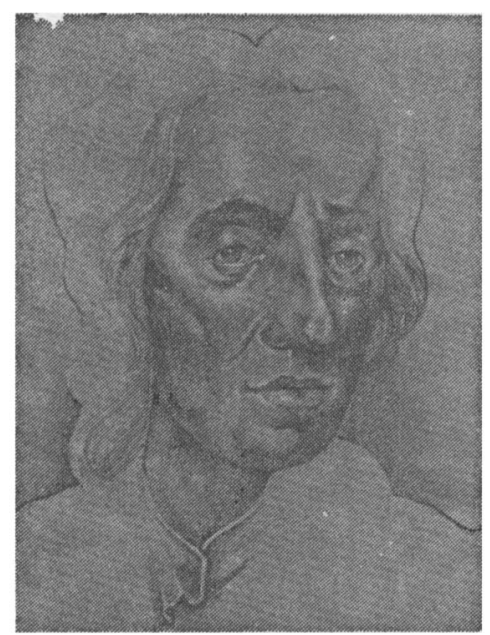

\section{JOHN LOCKE'S UBERALSM}

Ruth W. Grant

"A judicious and balanced work in the analytical tradition of Locke studies." - Geraint Parry, University of Manchester

Coth $\$ 24.95232$ pages 


\section{The Political Economy of Japan \\ VOLUME I: THE DOMESTIC TRANSFORMATION}

Edited by Kozo Yamamura and Yasukichi Yasuba. This is the first of three volumes that evaluate the political economy of Japan as it approaches the 1990's: the country's phenomenal economic rise, its society, and its place in contemporary world affairs. The result of the joint efforts of 19 Japanese and American scholars, these 13 papers provide accurate descriptions of changes since 1945- and especially since 1973-in the Japanese polity and economy, balanced analyses of the reasons for postwar Japan's performance, and credible predictions about Japan's political economy in future years.

Cloth \$37.50; paper, \$12.95

\section{Born Arming}

DEVELOPMENT AND MILITARY POWER

IN NEW STATES

A. F. Mullins, Jr. Concentrating on 46 countries that have achieved independence in the last 25 years, this book is a rigorous quantitative investigation of the relationship between military capability and political and economic development. It addresses the questions suggested by such a relationship: What conditions promote or inhibit the acquisition of military capability? Do these conditions change with time or geographical circumstances? And most important, how does growth in military capability itself affect the rate of development? $\$ 28.50$

\section{U.S.-Mexico Relations \\ AGRICULTURE AND RURAL DEVELOPMENT}

Edited by Bruce F. Johnston, Cassio Luiselli, Celso Cartas Contreras, and Roger D. Norton. The product of extensive collaboration between U.S. and Mexican scholars, these 18 papers provide a truly binational perspective on the structure, growth, and interrelationships of the farm systems of the United States and Mexico. The book examines the history of agricultural developments in the two countries, their agricultural trade, and such major policy issues as Mexico's Sistema Alimentario Mexicano. \$42.50

New in cloth and paper

\section{Taking Japan Seriously}

\section{A CONFUCIAN PERSPECTIVE ON LEADING ECONOMIC ISSUES}

Ronald Dore. Taking Japan seriously means more than being impressed by bits of Japanese social technology and seeking to borrow them. It means asking what is behind this social technology and what changes Britain and the United States must make in their industrial relations to move toward the economic successes of Japan. This book examines features of Japanese economic organization and policy-making that reveal alternatives not usually considered open to Western democracies. In many cases the Japanese system could be profitably imitated or reproduced in new forms, and Western economies have much to gain by taking these possibilities seriously. Cloth, \$35.00; paper, \$12.95

\section{Stanford University Press STANFORD, CA 94305}




\section{New Contributions to the Debate Over Socialism}

\section{from Greenwood Press and Praeger Publishers}

World Socialism at the Crossroads

An Insider's View

\section{by Silviu Brucan}

Brucan, a former Romanian Ambassador to the United States and the United Nations, contends that socialist countries are at a crossroads and must adapt their political ideology to the scientific-technological revolution.

October 1987. ISBN 0-275-02782-2 \$35.00 est. Praeger Publishers

\section{Prospects for Change in Socialist}

\section{Systems}

Challenges and Responses

edited by Charles J. Bukowski and

\section{Mark A. Cichock}

Recent changes and upheavals in the Soviet bloc suggest a growing potential for systematic restructuring within Eastern European socialist states. The contributors to this book examine the sociopolitical and economic systems of individual socialist countries and speculate about possible future developments.

1987. ISBN 0-275-92434-3 \$34.95

Praeger Publishers

\section{Neighborhood Justice in Capitalist} Society

The Expansion of the Informal State by Richard Hoftricher

Using a Marxist interpretation of recent developments in state-sponsored alternatives to courts for the resolution of disputes, this book explores the relationship between disruptions in reproducing the social order of American capitalism and transformations in the capitalist state that make these dispute resolution mechanisms possible.

1987. ISBN 0-313-25677-2 \$35.00 Greenwood Press
The French Socialist in Power, 1981-1986 edited by Patrick McCarthy

The only full-length study of the subject yet written, this book looks at the realities behind the French Socialist Party's coming to power - how it happened. what the Socialists achieved in the way of social change, where they failed. and what lasting impact their brief tenure is likely to have on French and European politics.

September 1987. ISBN 0-313-25407-9 \$39.95 Greenwood Press

\section{Socialist Authority}

The Hungarian Experience by Peter A. Toma

This study differentiates between the theory and practice of socialist authority in a vivid and lively analysis of how the people of Hungary learned to circumvent the restructions imposed by the regime and survive both internal and external pressures of socialism.

November 1987. ISBN 0-275-92602-8 \$40.00 est. Praeger Publishers

\section{Class In China \\ Stratification in a Classless Society by Larry $\mathbf{M}$. Wortzel}

This work presents one of the first comprehensive analyses of the class system in socialist China as it exists in practice rather than as conceived in theory. It then looks beyond China to draw more general conclusions about the structure of socialist political systems.

1987. ISBN 0-313-25498-2 \$32.95 Greenwood Press

\section{Available in Paperback}

The Soviet Union Under Gorbachev Assessing the First Year edited by Arthur B. Gunlicks and John D. Treadway

This concise anthology assesses the Soviet leader's first year in power and considers the prospects for economic reform, challenges and changes in social policy and the arts. and initiatives in foreign policy.

October 1987.

ISBN 0-275-92702-4

$\$ 13.00$ est. Praeger Publishers

\section{Soviet Politics from Brezhnev to Gorbachev} by Donald M. Kelley This work focuses on the political and institutional realities that shape contemporary Soviet politics by looking at individual leaders from Brezhnev to Gorbachev. September 1987. ISBN 0-275-92732-6 \$9.95 Praeger Publishers

\author{
Recapturing \\ Marxism \\ An Appraisal of Recent \\ Trends in Sociological \\ Theory \\ edited by \\ Rhonda F. Levine and \\ lerry Lembcke \\ This collection of essays \\ focuses on current efforts to \\ revitalize Marxist analysis in \\ sociology and examines the \\ emerging "new" establishment \\ within the discipline. \\ September 1987. \\ ISBN 0-275-92638-9 \\ $\$ 14.00$ est. Praeger Publishers
}

\section{Greenwood Press / Praeger Publishers}




\section{Vital Issues}

\section{Nuclear Blackmail and Nuclear Balance Richard K. Betts}

In numerous crises since WWII, the U.S. has resorted to vague threats to use nuclear weapons to deter Soviet or Chinese action. Betts suggests that U.S. presidents were neither consciously bluffing when they made these threats, nor were they prepared to face the consequences if their threats failed.

Paper \$10.95/Cloth \$28.95

\section{Perspectives on a U.S.- Canadian Free Trade Agreement \\ Robert M. Stern, Philip H. Trezise, and John Whalley, Eds.}

This timely volume offers a broad analysis of the current negotiations for a mutual free trade agreement between Canada and the United States.

Paper $\$ 12.95 /$ Cloth $\$ 32.95$

\section{Federal Tax Policy}

\section{Fifth Edition}

Joseph A. Pechman

One of the major architects of comprehensive tax reform has revised his widely acclaimed book on tax policy to reflect the changes brought about by the Tax Reform Act of 1986.

Paper \$10.95/Cloth \$28.95

\section{Creating the Computer} Government, Industry, and High Technology

\section{Kenneth Flamm}

The launching of the first electronic digital computers in the 1940 s signaled the beginning of a distinctive, new industry. Flamm traces the development of this industry-its emphasis on innovation and extensive research and development and its effects on international relations.

Paper \$10.95/Cloth \$28.95

\section{Space and National Security}

Paul B. Stares

Stares concludes that long before the Strategic Defense Initiative can demonstrate the feasibility of ballistic missile defense, it will foster a costly arms race with the Soviets and breed a new generation of more deadly antisatellite weapons. He argues instead for meañingful limitations on space weaponry.

Paper $\$ 10.95 /$ Cloth $\$ 28.95$

\section{Mergers, Sell-Offs, and Economic Efficiency}

\section{F. M. Scherer and David J. Ravenscraft}

Between 1950 and 1975 U.S. corporations achieved a two-fold increase in diversification, principally by acquiring other corporations. The authors examine how successful were those mergers and what are the implications of mergers for economic efficiency, productivity growth, managerial motivation, and public policy.

Paper $\$ 12.95 /$ Cloth $\$ 32.95$

Available in October

\section{FROM}

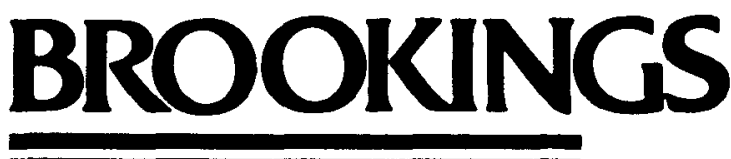

\section{What Should Banks Do?}

Robert E. Litan

Continuing technological advances, decontrol of deposit interest rates, and the removal of barriers to interstate bank expansion have ushered in a new age of competition. Litan offers a new and controversial proposal for carefully circumscribed diversification.

Paper \$9.95/Cloth $\$ 26.95$

\section{The Brookings Institution}

1775 Massachusetts Avenue, N.W.

Washington, D.C. 20036 (202) 797-6258 


\section{Wh INTRODUCING TWO IMPORTANT NEW BOOKS IN THE SUNY serles in AFRO-AMERICAN STUDIES John Howard and Robert C. Smith, Eds.}

\section{- Black Presidential Politics in America: A Strategic Approach by RONALD W. WALTERS \\ and \\ - Black Political Mobilization: Leadership, Power \& Mass Behavior by MINION K.C. MORRISON}

Black Presidential Politics

argues that blacks use the electoral system differently from other groups to achieve their social, political, and economic goals. Walters examines black participation in the politics of the primaries, party conventions, and general elections, showing the results of both traditional behind-the-scenes bargaining (dependent leverage) and the more recent direct entry into the presidential selection process as candidates (independent leverage). A veteran political scientist and an active participant in Jesse Jackson's 1984 presidential campaign, Walters deals with the most significant topics in black politics studies and electoral studies in general.

Ronald W. Walters is Professor of Political Science at Howard University.

\section{CONTENTS}

- Evolution of Black Electoral Theory • Balance of Power and Dependent Leverage - Strategy of Political Integration - Black Agenda-Building Process • Independent Leverage Strategies - Inter-Party Scenarios: The Black Independent Party • Intra-Party Scenarios: The Jackson Campaign for the Democratic Party Presidential Nomination - Leverage Strategies and the Future

$\$ 14.95$ pb. / 0-88706-547-3 $\$ 44.50$ hc. / 0-88706-546-5
In Black Political Mobilization, Minion Morrison returns to Mississippi, the center of much of the political activism of the 1960 s, to analyze the remarkable improvement in black electoral participation in the years following passage of the Voting Rights Act of 1965. Through in-depth study of three rural towns, the author presents examples of the character and process of minority electoral politics and mobilization in the South: a new class of black leaders is nurtured and installed in office in an environment where a newly and highly mobilized constitutency takes advantage of its minority status in the electorate.

Minion K.C. Morrison is Associate Professor of Afro-American Studies and Political Science and Chairman of the AfroAmerican Studies Department at Syracuse University.

\section{CONTENTS}

- The American Political System and Mobilization Politics $\bullet$ Black and White in the Southern Regional Context $-N e o-$ Populism in Bolton - Heroine in Mayersville - Agrarian Townsman in Tchula $\cdot$ The Electorates: Politics, Economics and Ideology • The Political Economy of Rural Black-American Mobilization

\section{$\$ 19.95$ pb. / 0-88706-516-3} $\$ 49.50$ hc. / 0-88706-515-5

\section{STATE UNIVERSITY OF NEW YORK PRESS}

P.O. Box 6525 • Ithaca, NY $14850 \cdot(607) 277-2211$ 


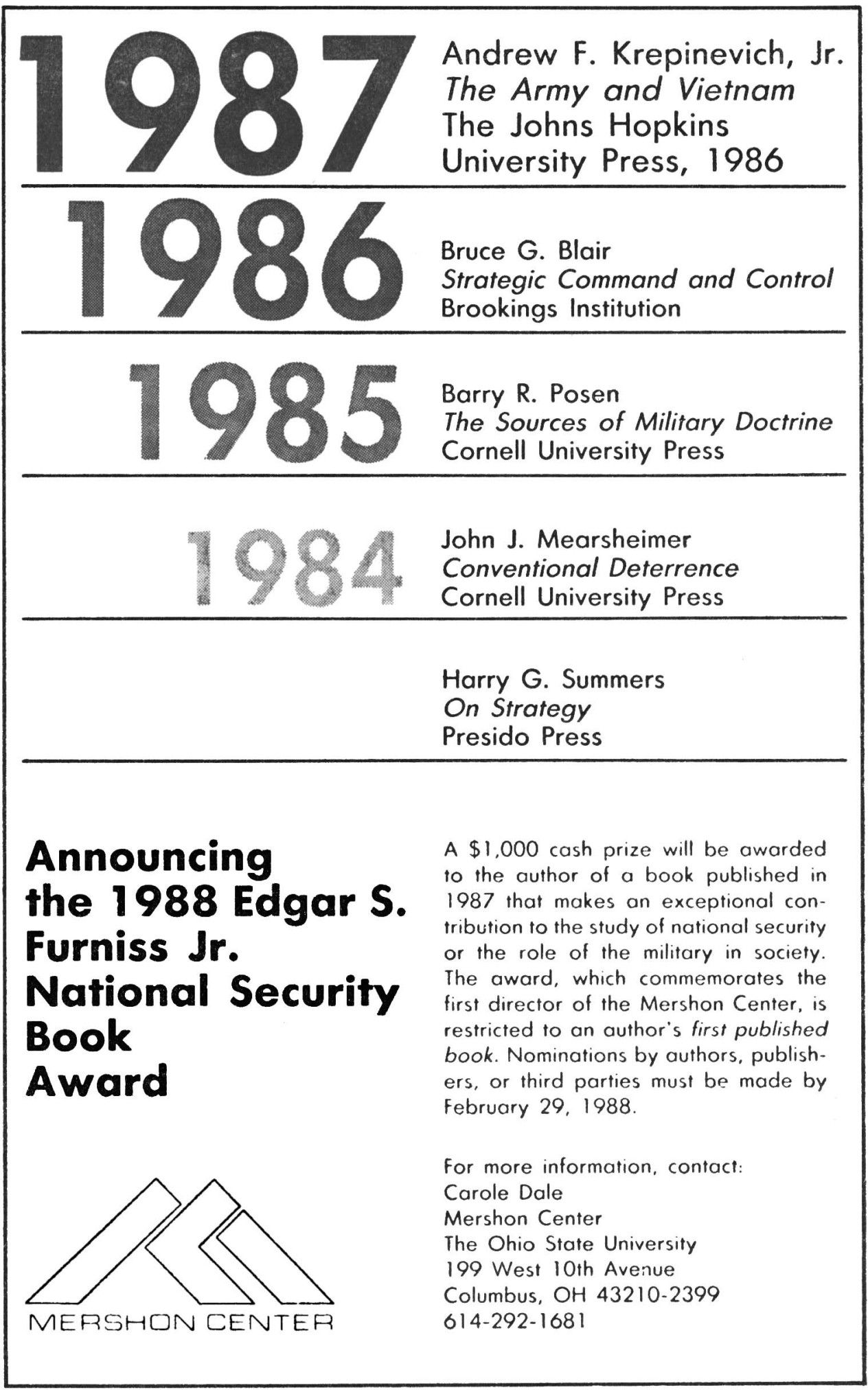




\section{Princeton University Press}

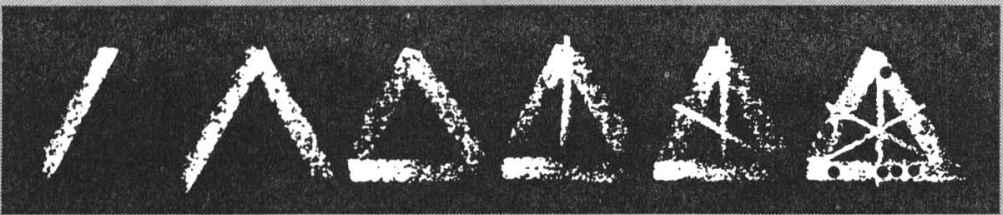

\section{Multinationals, The State, and Control of the Nigerian Economy \\ Thomas J. Biersteker}

Thomas Biersteker evaluates the sources of Third World economic nationalism and assesses the significance of the changes that have taken place worldwide since the early 1970s. Neo-classical and neo-Marxist approaches to international and comparative political economy are explored to develop methods and select criteria for the assessment of major change. The book is based on extensive interview material, access to previously unpublished documents, and data assembled on every large company incorporated in Nigeria.

Paper: $\$ 12.50$. Cloth: $\$ 45.00$

\section{Meeting Needs \\ David Braybrooke}

Every day, throughout the world, the concept of needs works to sort out social policies. Yet the idea is in disrepute with many thinkers who, led by economists, accuse it of being too fluid, or too narrow, or of serving no purpose that the concept of preferences does not serve better. David Braybrooke refutes these charges by providing a model of how the concept of needs works. Ascribing needs across whole populations at once and tying them to a criterion of adequate functioning, the model allows for variations among people in minimum standards of provision and expands or contracts to deal with conventional aspects of needs.

Studies in Moral, Political, and Legal Philosophy

Marshall Cohen, Editor

Paper: $\$ 12.50$. Cloth: $\$ 35.00$

\section{At your bookstore or}

Princeton University Press

41 William Street, Princeton, NJ 08540

(609) 896-1344 


\section{Chatham House \\ Box One, Chatham, New Jersey o7928 Telephone: (201) 635-2059}

THE THEORY OF DEMOCRACY REVISITED

Vol. I, The Contemporary Debate. Vol 2, The Classical Issues.

Giovanni Sartori

"Everyone seriously interested in democratic theory will welcome the appearance of The Theory of Democracy Revisited. His earlier Democratic Theory made a vigorous, vital, and distinguished contribution to our contemporary understanding of democratic theory. In the new book Sartori takes later discussions into account where they are appropriate. I expect to readers a generation from now the revision will still be a fresh and lively interpretation of democratic theory."

Robert A. Dahl, Yale University

"Democracy is, in part, a debate about what democracy is. With The Theory of Democracy Revisited, Sartori offers an overview of classical and contemporary issues. All students of politics will find his arguments provocative, whether or not they agree with his conclusions."

Jean Bethke Elshtain, University of Massachusetts, Amberst 0-934540-46-2 cloth 0-934540-49-7 2-volume set, paper

\section{MEDIA AND MOMENTUM}

The New Hampshire Primary and Nomination Politics Edited by Gary R. Orren and Nelson W. Polsby

"It is said that we do have a national presidential primary. It's just that it occurs in New Hampshire. Orren and Polsby have collected excellent, insightful papers on this extraordinarily important contest. Political scientists, journalists, maybe even candidates and their staffs will profit from reading this book."

Charles O. Jones, University of Virginia

"Everything you might want to know about the history, significance, and yes, the foolishness of the New Hampshire primary. And, for your favorite candidate there's even an appendix that outlines the political demography of this tiny, but mighty, electorate."

0-934540-66-7 paper

Michael J. Robinson, Georgetown University 0-934540-67-5 cloth

\section{CITIZEN POLITICS IN WESTERN DEMOCRACIES} Public Opinion and Political Parties in the United States, Great Britain, West Germany, and France

Russell J. Dalton

Will serve as a core text for undergraduate courses in West European politics, comparative parties, and comparative public opinion. Dalton explains how citizens perceive political parties and the political system, how they try to influence the political process, and how voting decisions are made. The book is structured around the theme that the values and political sophistication of Western publics have undergone a major transformation over the past 20 years, leading to declining trust in government, an increase in protest and other forms of direct political action, and the decay of party alignments.

0-934540-44-6 paper

Forthcoming

For further information about these and forthcoming titles, please contact Edward Artinian, publisher, CHATHAM HOUSE PUBLISHERS, Box One, Chatham, N.J. 07928. Telephone: (201) 635-2059. 


\section{INSTRUCTIONS TO CONTRIBUTORS}

The American Political Science Review aims to publish scholarly research and writing of exceptional merit. Contributions must demonstrate the highest standards of excellence in conceptualization, exposition, methodology, and craftsmanship. Because the Review reaches a diverse audience of scholars and practitioners, contributors must demonstrate how their analysis or exposition illuminates a significant research problem, or answers an important research question, of general interest in political science.

\section{Article Manuscripts}

Article manuscripts should be submitted to the Managing Editor, Professor Samuel C. Patterson, American Political Science Review, Department of Political Science, Ohio State University, 112 Derby Hall, Columbus, Ohio 43210-1373. Four copies must be submitted, and none can be returned. Manuscripts must be typed double-spaced, on only one side of the paper. The author's name and affiliation should not appear on the copies submitted, but only on a separate covering sheet. An abstract of no more than $\mathbf{1 5 0}$ words must be sent with the manuscript. In general, the Review considers manuscripts of up to 30 pages in length. Moreover, the Review does not consider manuscripts submitted to other publications.

Manuscripts should be prepared following the guidelines of the APSA Style Manual, a publication of the American Political Science Association's Committee on Publications. It is available from the Managing Editor's office. Otherwise, authors should follow the Chicago Style Manual and the example of recent issues of the Review. Graphs and tables should be presented on separate pages, with their location in the manuscript indicated, e.g., the notification "Table 1 about here," at the proper places.

\section{Book Reviews}

Books intended for review and all book review correspondence should be sent to the
Book Review Editor, Professor Robert $\mathrm{H}$. Salisbury, American Political Science Review, Department of Political Science, Washington University, Campus Box 1063, St. Louis, Missouri 63130.

\section{Other Correspondence}

Information, including news and notes, for the Association's news journal, PS, should be sent to Dr. Catherine E. Rudder, Editor, American Political Science Association, 1527 New Hampshire Avenue, N.W., Washington, D.C. 20036. Advertising, reprint, and circulation correspondence should be sent to the Executive Director at the Washington office. Domestic claims for nonreceipt of issues must be made within four months of the month of publication; overseas claims, eight months. Advertising information and rates are available from Norinne Hessman, Advertising Manager, APSA, 1527 New Hampshire Avenue, N.W., Washington, D.C. 20036.

\section{Indexing}

Articles and notes appearing in the Review before the June 1953 issue were indexed in The Reader's Guide to Periodical Literature. Current issues are indexed by International Political Science Abstracts, United States Political Science Documents, and Social Sciences and Humanities Index. Microfilm of the Review, beginning with Volume 1, may be obtained from University Microfilms, 300 North Zeeb Road, Ann Arbor, Michigan 48106. A Cumulative Index of the Review, Volumes 1-62, 1906-1968, also may be obtained from University Microfilms. Articles appearing in the Review are listed in $A B C$ Pol Sci and Current Contents: Behavioral, Social $\&$ Management Sciences. Book reviews are indexed in Book Review Index. 


\section{CONTENTS}

\section{ARTICLES}

War Cues and Foreign Policy Acts

Francis A. Beer, Alice F. Healy,

Grant P. Sinclair \& Lyle E. Bourne, Jr. . . . . . . . . . . . . . . . . . . . 701

Crisis Bargaining, Escalation, and MAD

Robert Powell

Fleeing the Iron Cage: Politics and Culture in

the Thought of Max Weber

Lawrence A. Scaff

The Individual Political Economy of Federal

Tax Policy

Michael R. Hawthorne \& John E. Jackson

The Dynamics of Structural Realignment

Stuart Elaine Macdonald \& George Rabinowitz

State Political Culture and Public Opinion

Robert S. Erikson, John P. McIver,

\& Gerald C. Wright, Jr.

Television News and Citizens' Explanations of

National Affairs

Shanto lyengar

Threat Escalation and Crisis Stability:

A Game-theoretic Analysis

Steven J. Brams \& D. Marc Kilgour

Bureaucratic Politics in Radical Military Regimes

Gregory J. Kasza

Stacking the Deck: Bureaucratic Missions and Policy Design

Jonathan Bendor, Serge Taylor

\& Roland Van Gaalen .

Asymmetric Information and the Coherence of Legislation

David Austen-Smith \& William H. Riker

CONTROVERSIES

Liberalism, Human Rights, and Human Dignity

Neil Mitchell, Rhoda E. Howard

\& Jack Donnelly

Why are Congressional Committees Powerful?

Keith Krehbiel, Kenneth A. Shepsle

\& Barry R. Weingast ............................. 92

RESEARCH NOTES

Guns and Butter and Government Popularity in Britain

Helmut Norpoth

Nationalization of the Electorate in the United States

Laura L. Vertz, John P. Frendreis

\& James L. Gibson .

BOOK REVIEWS

Political Theory $\ldots \ldots \ldots \ldots \ldots \ldots \ldots \ldots \ldots \ldots \ldots \ldots \ldots \ldots, 973$

American Politics .................................. 990

Comparative Politics ............................... 1016

International Relations ............................. 1039

Political Economy ................................. 1054 